Aus der Klinik für Dermatologie, Venerologie und

Allergologie

(Prof. Dr. med. M. P. Schön)

der Medizinischen Fakultät der Universität Göttingen

\title{
Differential responses of human melanoma cells to c-Rel down- regulation
}

\author{
INAUGURAL-DISSERTATION \\ zur Erlangung des Doktorgrades \\ der Medizinischen Fakultät der \\ Georg-August-Universität zu Göttingen
}

vorgelegt von

Marie Kristin Priebe

aus

Bremerhaven

Göttingen 2019 
Dekan: $\quad$ Prof. Dr. rer. nat. H. K. Kroemer

Referentin: $\quad$ Prof. Dr. med. C. S. Seitz

Ko-Referent/in:

Drittreferent/in:

Datum der mündlichen Prüfung: 
Hiermit erkläre ich, die Dissertation mit dem Titel "Differential responses of human melanoma cells to c-Rel down-regulation" eigenständig angefertigt und keine anderen als die von mir angegebenen Quellen und Hilfsmittel verwendet zu haben.

Göttingen, den

(Unterschrift) 
Ergebnisse dieser Arbeit wurden bereits veröffentlicht in:

Priebe MK, Dewert N, Amschler K, Erpenbeck L, Heinzerling L, Schon MP, Seitz CS, Lorenz VN (2019): cRel is a cell cycle modulator in human melanoma cells. Exp Dermatol 28: 121-128. 


\section{Content}

\section{List of Figures ........................................ 5}

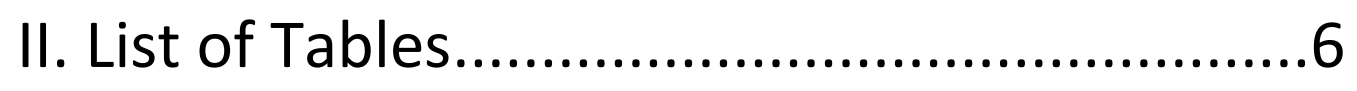

III. Abbreviations .......................................

1. Introduction ......................................... 11

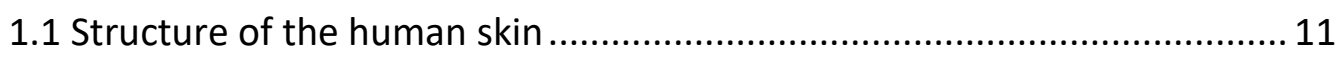

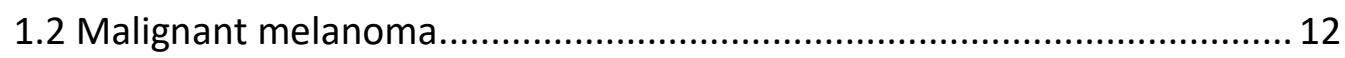

1.2.1 Risk factors and clinical subtypes ............................................... 12

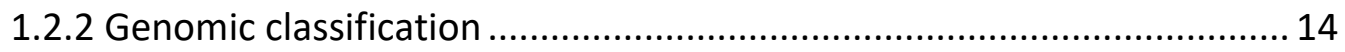

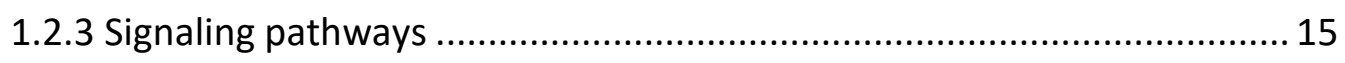

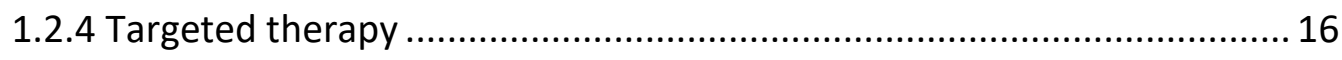

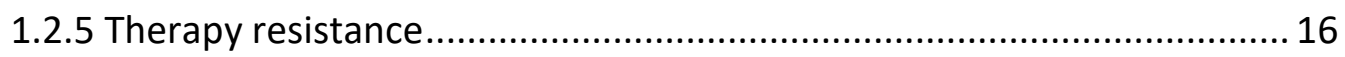

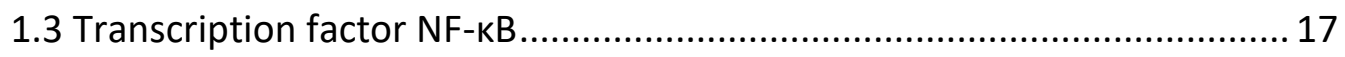

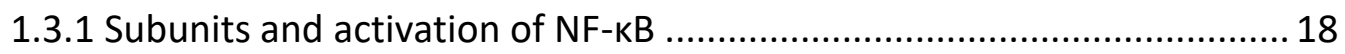

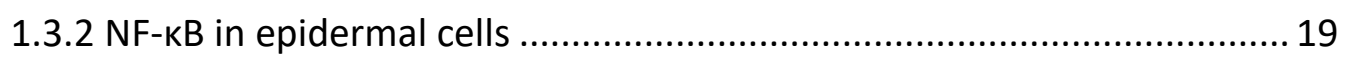

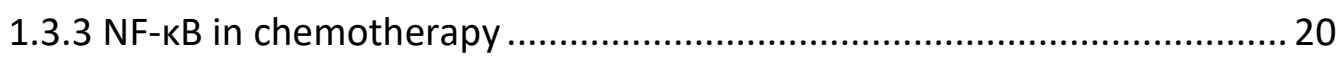




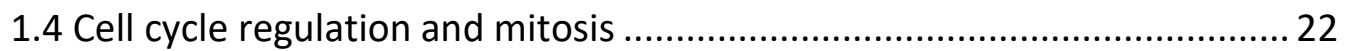

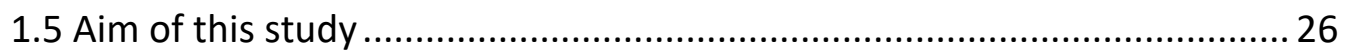

\section{Material and Methods....................... 27}

2.1 Materials.

2.2 Methods 38

2.2.1 Cell culture 38

2.2.1.1 Cultivation of melanoma cell lines 38

2.2.1.2 Cell Counting. 39

2.2.1.3 Cryopreservation 39

2.2.1.4 siRNA transfection 40

2.2.2 Growth curve generation 40

2.2.3 Protein extraction .40

2.2.4 Western Blotting......

2.2.5 RNA isolation

2.2.6 cDNA synthesis

2.2.8.1 MTT cell viability assay 
3.2 Efficient siRNA transfection and c-Rel down-regulation in cell lines A375 and LOX

3.3.3 c-Rel down-regulation affects cell cycle phase distribution and mitosis 61

\section{Discussion}


4.3 c-Rel modifies cell cycle phase distribution and mitotic spindle formation

\section{Summary and conclusion ................... 73}

6. Literature ........................................ 74 


\section{List of Figures}

Figure 1: Schematic structure of the human epidermis (adapted from Maru et al. 2014)

Figure 2: Scheme of typical NF-kB Signal transduction pathways (adapted from Gilmore 2006).

Figure 3: Schematic representation of the cell cycle phases and mitosis (adapted from Walczak et al. 2010).

Figure 4: Melanoma cell lines show different phenotypes and growth rates. 51

Figure 5: Melanoma cells have different levels of c-Rel expression.

Figure 6: Efficient transfection and c-Rel down-regulation in A375 and LOX cells. . .55

Figure 7: Efficient siRNA transfection by high siRNA concentration. 56

Figure 8: c-Rel down-regulation reduces cell growth. 58

Figure 9: Apoptosis rate in LOX cells is increased by c-Rel down-regulation.. 60

Figure 10: c-Rel down-regulation changes cell cycle phase distribution 62

Figure 11: c-Rel down-regulation leads to an increase of aberrant mitotic cells in cell line LOX. 65 


\section{List of Tables}

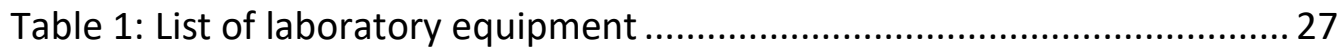

Table 2: List of disposable/re-usable material ............................................. 29

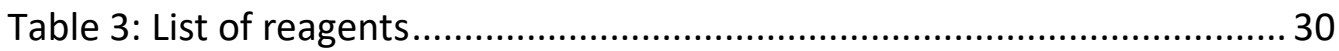

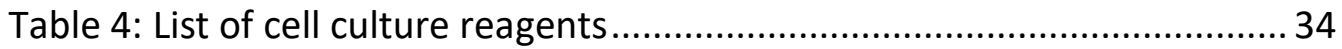

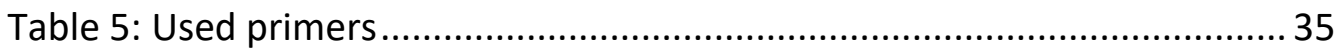

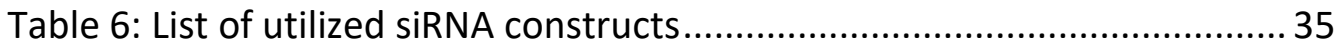

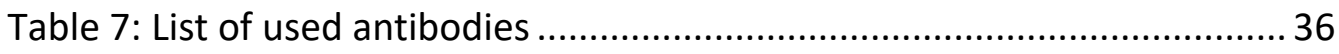

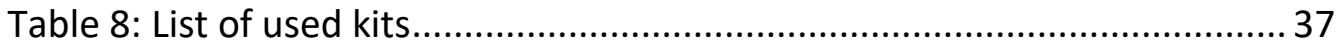

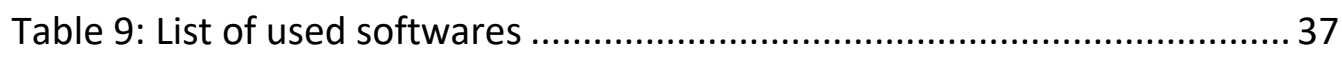

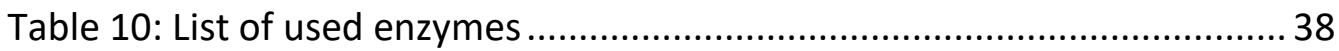

Table 11: List of used melanoma cell lines ................................................. 38

Table 12: Concentrations of PCR components .............................................. 43

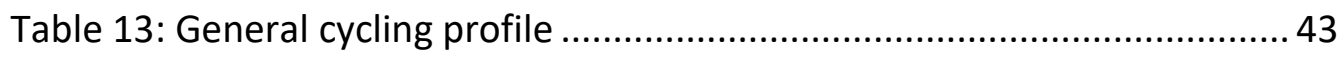




\section{Abbreviations}

\pm SEM standard error of the mean

A375 human melanoma cell line A375

ABTS 2,2'-azino-bis(3-ethylbenzothiazoline-6-sulphonic acid)

AKT protein kinase-B

ALM acral lentiginous melanoma

Apaf-1 apoptotic protease activating factor 1

Bcl-xl B-cell lymphoma-extra large

BRAF B-Raf proto-oncogene

BrdU bromodeoxyuridine

BSA bovine serum albumine

BubR1 budding uninhibited by benzimidazole

Casp9 Caspase-9

CDK cyclin-dependent kinase

CDKN2A cyclin-dependent kinase inhibitor 2A locus

cDNA complementary deoxyribonucleic acid

CFLIP FLICE-like inhibitory protein

FOXM1 forkhead box protein M1

CIN chromosomal instability

CPC chromosome passenger complex

CTNNB1 gene encoding $\beta$-Catenin

DAPI 4',6-diamidino-2-phenylindole

$\mathrm{ddH}_{2} \mathrm{O} \quad$ double distilled water

DEPC diethylpyrocarbonate

DMEM Dulbecco's modified eagle medium

DNA deoxyribonucleic acid

EDTA ethylenediaminetetraacetic acid

e.g. (exempli gratia) for example

ERK extracellular signaling-regulated kinase

EtOH ethanol 


\begin{tabular}{|c|c|}
\hline FACS & fluorescence-activated cell sorting \\
\hline FasL & Fas ligand \\
\hline FCS & fetal calf serum \\
\hline FDA & U.S. Food and Drug administration \\
\hline CFLIP & FLICE-like inhibitory protein \\
\hline g & gravitation \\
\hline GAPDH & glyceraldehyde 3-phosphate dehydrogenase \\
\hline GAPs & GTPase activating proteins \\
\hline GDP & guanosine-diphosphate \\
\hline GNAQ & guanine nucleotide-binding protein $\mathrm{G}(\mathrm{q})$ subunit alpha \\
\hline GNA11 & guanine nucleotide-binding protein subunit alpha-11 \\
\hline GPCR & G-protein-coupled receptors \\
\hline GTP & guanosine-5-triphosphate \\
\hline h & hour \\
\hline HRP & horseradish peroxidase \\
\hline IAP & the inhibitor of apoptosis \\
\hline IKB & inhibitory proteins of the ІкB family \\
\hline IKK & IкB kinase complex \\
\hline INCENP & inner centromere protein \\
\hline KINK-1 & kinase inhibitor of nuclear factor-kappaB-1 \\
\hline KIT & type III receptor tyrosine kinase \\
\hline K-Ras & KRAS proto-oncogene \\
\hline LM & lentiginous melanoma \\
\hline LOX & human melanoma cell line \\
\hline MAD2 & Bub3 and mitotic arrest deficient \\
\hline MAPK & mitogen-activated protein kinase cascade \\
\hline MCC & mitotic checkpoint complex \\
\hline MEK & mitogen-activated protein kinase kinase \\
\hline Mel2a & human melanoma cell line Mel2a \\
\hline MeWo & human melanoma cell line MeWo \\
\hline $\mathrm{MMNH}$ & human melanoma cell line $\mathrm{MMNH}$ \\
\hline MPM-2 & mitotic protein monoclonal 2 \\
\hline
\end{tabular}




\begin{tabular}{|c|c|}
\hline MTT & $\begin{array}{l}\text { 3-(4,5-dimethylthiazol-2-yl)-2,5-diphenyltetrazolium } \\
\text { bromide }\end{array}$ \\
\hline MV3 & human melanoma cell line MV3 \\
\hline NBD & NEMO-binding domain \\
\hline NEMO & NF-KB essential modulator \\
\hline NF1 & neurofibromatosis 1 \\
\hline NF-KB & nuclear factor-'kappa-light-chain-enhancer' of activated B \\
\hline NIK & NF-kB-inducing kinase \\
\hline NM & nodal melanoma \\
\hline OSCC & oral skin cancer cells \\
\hline $\mathrm{p} 27$ & cyclin-dependent kinase inhibitor 1B \\
\hline p53 & tumor suppressor 53 \\
\hline PBS & phosphate-buffered saline \\
\hline $\mathrm{p}-\mathrm{H} 3^{\operatorname{Ser} 10}$ & phospho-histone $\mathrm{H} 3$ \\
\hline $\mathrm{Pl}$ & propidium iodide \\
\hline PI3K & phosphatidylinositol-4,5-bisphosphate 3-kinase \\
\hline PTEN & phosphatase and tensin homolog \\
\hline RAS & Ras (rat sarcoma) proto-oncogene \\
\hline RB & retinoblastoma protein \\
\hline RHD & Rel homology domain \\
\hline rpm & revolutions per minute \\
\hline RT & room temperature \\
\hline RTKs & receptor tyrosine kinases \\
\hline RT-PCR & reverse transcription-polymerase chain reaction \\
\hline SAC & spindle assembly checkpoint \\
\hline SCC & squamous cell carcinoma \\
\hline SDS & sodium dodecyl sulfate \\
\hline SDS-PAGE & $\begin{array}{l}\text { sodium dodecyl sulfate polyacrylamide gel } \\
\text { electrophoresis }\end{array}$ \\
\hline SiRNA & small interfering RNA \\
\hline Sk-Mel-23 & human melanoma cell line Sk-Mel-23 \\
\hline SSM & superficial spreading melanoma \\
\hline
\end{tabular}




$\begin{array}{ll}\text { TAD } & \text { terminal transactivation domain } \\ \text { TNF- } \alpha & \text { tumor necrosis factor-alpha } \\ \text { TNFR } & \text { tumor necrosis factor receptor } \\ \text { TRAF-1 } & \text { tumor necrosis factor receptor-associated factor 1 } \\ \text { TRAIL } & \text { tumor necrosis factor-related apoptosis-inducing ligand } \\ \text { TRIS } & \text { tris(hydroxymethyl)aminomethane } \\ \text { TRK } & \text { total RNA Kit I } \\ \text { UVR } & \text { ultraviolet radiation } \\ \text { V600E } & \text { valine at residue } 600 \text { mostly with glutamic acid } \\ \text { V-Rel } & \text { the avian mutated homologue of c-Rel } \\ \text { WT } & \text { wild-type }\end{array}$




\section{Introduction}

\subsection{Structure of the human skin}

The human skin in its function is essential in protecting the organism against physical and biochemical stress as well as ultraviolet radiation (UVR). According to different requirements, the human skin is comprised of epidermis, dermis, and subcutaneous layers. Again, the epidermis gets subdivided into stratum corneum (the outermost layer), - granulosum, - spinosum, and - basale. Several different cell types are found in the human skin - predominantly keratinocytes as well as melanocytes, Merkel-cells, and Langerhans-cells (Figure 1). Regarding the relative proportion of different cell types, melanocytes represent about $1 \%$ of all cells and are located next to basal keratinocytes. The main function of melanocytes is the production of melanin. Melanin is incorporated by surrounding keratinocytes and accumulates perinuclearly, thereby protecting the nucleus from about $50-75 \%$ of UV radiation. On the one hand this protective shield scatters UV radiation, while on the other hand it serves as an absorbing filter reducing the UV penetration and its subsequent potential DNA damage (Brenner and Hearing 2008; Proksch et al. 2008). 


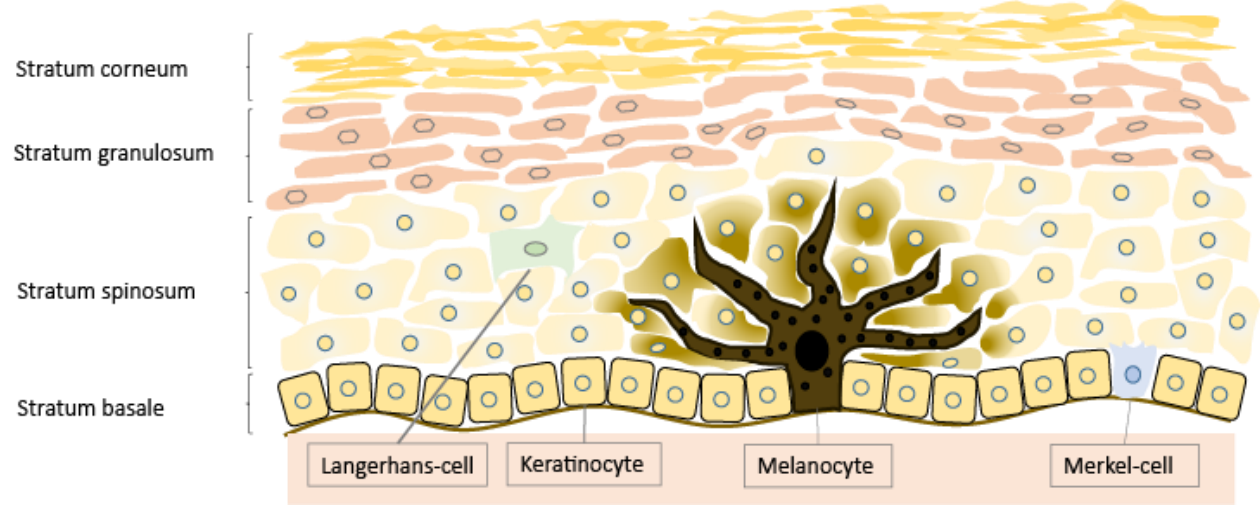

Figure 1: Schematic structure of the human epidermis (adapted from Maru et al. 2014).

The epidermis is subdivided in four different layers: Stratum corneum (the outermost layer), granulosum, - spinosum, and - basale, which are mostly comprised of keratinocytes and also contain other cell types such as melanocytes, Merkel-, and Langerhans-cells. Melanocytes are located in the stratum basale producing melanin in specific organelles called melanosomes. Each melanocyte releases melanin via dendritic branches incorporated by surrounding cells.

\subsection{Malignant melanoma}

\subsubsection{Risk factors and clinical subtypes}

Compared to other forms of skin cancer, malignant melanoma shows the most aggressive growth pattern, revealing a steadily increasing incidence rate in recent years (Gandini et al. 2005; Madonna et al. 2012).

Risk factors for melanoma include UVR, multiple moles, family history, fair skin, and immunosuppression. In several epidemiologic studies it was demonstrated that severe sunburns during childhood and intermittent, but intense exposure to UVR lead to a high risk of malignant melanoma (Gandini et al. 2005; Whiteman et al. 2001).

In view of different skin types, fair skin types I and II show a higher incidence rate of malignant melanoma compared to skin types III and IV. Other predisposing risk factors for malignant melanoma comprise multiple nevi ( $\geq 100$ nevi), the atypical nevi-syndrome ( $\geq 5$ atypical nevi and $\geq 50$ common melanocytic nevi), $\geq 5$ atypical nevi in families with a higher melanoma risk, and past medical history of malignant melanoma (Leitlinienprogramm-Melanom 2016). 
It was shown that melanoma can develop from pre-existing nevi in about 20-40 $\%$ of cases, while the other $60-80 \%$ of cases were supposed to occur de novo (Eggermont et al. 2014).

Malignant melanoma may be subdivided into four different types: superficial spreading melanoma (SSM), nodular melanoma (NM), lentigo maligna melanoma (LMM) and acral lentiginous melanoma (ALM) (Saldanha et al. 2006). In $65 \%$ of the cases SSM is detected, hence representing the most common type. It is generally located in intermittently sun-exposed skin such as the trunk, extremities, head and neck (Greenwald et al. 2012). Two growth phases of SSM are described: the radial and the vertical growth phase. In the radial phase, the lesion expands along and within the epidermis. In the following vertical growth stage, the lesion spreads vertically, affecting the papillary dermis and probably the subcutaneous fat as well (Kwong et al. 2007).

With an incidence rate of about $20 \%$ of cases, NM arises with less of a radial growth phase and an increased vertical growth phase. In comparison to other melanoma subtypes, a higher Breslow's depth is found when the NM is diagnosed, caused by its tendency for vertical growth. Consequently, the patients that suffer from NM have a worse prognosis (Egger et al. 2012).

LMM mainly develops in chronically sun-exposed skin (mainly affecting the face) of elderly individuals. When it progresses to its invasive form, it is called LMM. This appears in $5 \%$ to $50 \%$ of cases (Samaniego and Redondo 2013).

A rare subtype is the ALM, which mainly arises acrally such as on the palms, soles and nail organs. The ALM is the most frequent subtype of melanoma among dark-colored people (Goydos and Shoen 2016).

Regarding prognosis of malignant melanoma, the Breslow's depth currently represents the most relevant factor of prognosis. Breslow's depth is determined by measuring the tumor depth from the granular layer of the epidermis down to the deepest point of invasion. Additionally, ulceration of the tumor, progression and mitosis rate in primary melanoma $\leq 1 \mathrm{~mm}$ are prognostic factors (Azzola et al. 2003; Balch et al. 2009). 


\subsubsection{Genomic classification}

In the past two decades, the detection of frequent mutations in melanoma has greatly improved due to revolutionary changes in the characterization of melanoma genome (Lo and Fisher 2014).

Analysis of mutations in 21 genes in melanoma cells showed that $46 \%$ were mutated, of which $37 \%$ were caused by C-to-T and $9 \%$ by G-to-T-mutations. Interestingly, these characteristics of UVR-induced mutations are mainly found in tumor suppressor genes, which include CDKN2A and PTEN (Hodis et al. 2012). In fact, mutations in CDKN2A locus are very frequent and considered to be associated with about $45 \%$ of familial melanomas, thereby representing the most common gene locus in view of hereditary melanoma (Soura et al. 2016). The two proteins $\mathrm{p} 16$ and $\mathrm{p} 14$, which are relevant for cell cycle progression, are encoded by CDKN2A locus. In detail, p16 is an inhibitor of cyclin-dependent kinase (CDK) 4 and CDK6, thus preventing the phosphorylation of retinoblastoma protein (RB1). By hypophosphorylation, the induction of S-phase genes and initiation of G1-to-S transition is prevented (Hayward 2003).

In terms of mutated tumor suppressor genes in malignant melanoma, PTEN gene mutation is highly frequent and occurs in up to $30 \%$ of melanomas. This mutation causes a loss of the lipid phosphatase and tensin homolog (PTEN), leading to an increased activation of the PI3K-AKT pathway, an important pathway of melanoma cells for cell survival and proliferation (Peng et al. 2016). Classifying malignant melanoma based on its mutational status, 'The Cancer Genome Atlas Network' defined four subtypes according to the following most prevalent significantly mutated genes: B-Raf proto-oncogene (BRAF), Ras (Rat sarcoma) proto-oncogene (RAS), Neurofibromatosis 1 (NF1), and Triple-WT (wild-type) (Cancer Genome Atlas 2015).

$B R A F$ mutations are the most common mutations of melanomas and may be found in over $50 \%$ of cases. Besides other mutations, the substitution for the valine at residue 600 mostly with glutamic acid (V600E) is found in over $90 \%$ of all $B R A F$ mutations. In context of UVR-exposure, $B R A F^{V 600 E}$ melanomas are more frequently found in intermittently sun-exposed areas (Curtin et al. 2005). The mutation V600E is a gain-of-function mutation which increases the activity of the BRAF kinase and thus enhances the activity of the mitogen-activated protein 
kinase (MAPK) cascade, thereby enhancing cell cycle progression and cell growth (Smalley 2010).

A second major subtype comprises RAS hot-spot mutations, including amino acid changes in all three RAS family members ( $\mathrm{N}-, \mathrm{K}-$, and $\mathrm{H}-\mathrm{RAS})$. NRAS somatic hot-spot mutations were detected in 10-25 \% of melanoma cells (Cancer Genome Atlas 2015). NRAS mutations also activate MAPK signaling similar to BRAF mutations. Infrequently, mutations in the Phosphatidylinositol-4,5bisphosphate 3-kinase (PI3K)-AKT pathways are also found in case of NRAS mutations, inducing cell proliferation, cell survival and cell cycle dysregulation (Johnson and Puzanov 2015).

According to genomic classification of melanoma cells by 'The Cancer Genome Atlas Network', another highly frequent mutational subtype includes mutations of NF1 gene in $14 \%$ of samples (mostly loss-of-function) (Cancer Genome Atlas 2015). NF1 is a GTPase-activating protein, which downregulates RAS activity by hydrolysing GTP (Guanosine-5-triphosphate) to GDP (Guanosine-diphosphate). Hence, a loss-of-function mutation of NF1 can be considered as an alternative way for activation of MAPK signaling pathway (Nissan et al. 2014).

Representing the fourth subtype, the Triple-WT is a heterogeneous subgroup, which lacks $B R A F, N / H / K-R A S$, or NF1- mutations. In this subgroup, other lowfrequency driver mutations such as KIT (KIT proto-oncogene receptor tyrosine kinase) were found among others (CTNNB1, GNAQ, GNA11). Activating KIT mutations may be detected in about $30 \%$ of mucosal, $20 \%$ of acral, and $20 \%$ of melanoma. In dependence of the cellular context that activates KIT (type III receptor tyrosine kinase), downstream effectors include the p85 subunit of PI3K and MAPK signaling pathway among others (Slipicevic and Herlyn 2015).

\subsubsection{Signaling pathways}

Regarding frequent mutations in melanoma cells, such as $B R A F, R A S(\mathrm{~N} / \mathrm{H} / \mathrm{K})$, NF1 and PTEN, there is evidence that these are in part driven by MAPK signaling (Hodis et al. 2012). This signaling pathway is mainly involved in cell cycle progression and cell growth. Extracellular mitogens activate receptor tyrosine kinases (RTKs), which stimulate the RAS proteins ( $\mathrm{H}-, \mathrm{N}-$, and KRAS). Again, activated RAS eventually leads to activation of the mitogen-activated protein kinase (MEK) $1 / 2$ and extracellular signaling-regulated kinase (ERK) 1/2 kinases. 
In turn, ERK influences cell cycle progression by regulating the transcription of proteins like cyclin D1 and cyclin-dependent kinase inhibitor 1B (p27). Additionally, phosphorylated ERK regulates transcription factors promoting the transformed phenotype, as well as several genes influencing the activity of RTKs, RAS and RAF, thereby negatively inhibiting pathway output (Nissan et al. 2014; Smalley 2010).

Besides the MAPK signaling pathway, the PI3K-AKT pathway plays a critical role within PTEN and NRAS mutated melanoma cells by regulating cell proliferation and survival (Madhunapantula et al. 2011).

\subsubsection{Targeted therapy}

Identification and functional analyses of frequent gene mutations and downstream signaling pathways in melanoma cells allowed promising new approaches concerning targeted therapy in the past years (Lo and Fisher 2014). Hence, a screening for underlying mutations to determine a targeted therapy of malignant melanoma is recommended (Leitlinienprogramm-Melanom 2016).

Elucidating the role of $B R A F^{V 600 E}$ mutation led to development of selective smallmolecule inhibitors of V600-mutant BRAF proteins like vemurafenib and dabrafenib, which showed substantial improvements in view of clinical response rate (about $48 \%$ overall) and progression free survival. Hence, these therapeutics were approved by the U.S. Food and Drug Administration (FDA) for therapy of advanced BRAF-mutant melanoma in 2011 (vemurafenib) and 2013 (dabrafenib) (Lo and Fisher 2014).

Notably, BRAF inhibitors can lead to paradoxical hyperactivation of CRAF in cells, which contain wild-type BRAF. Thereby, they induce an upstream of MAPK pathway activation. Consequently, a combined use of BRAF inhibitor dabrafenib and MAPK kinase (MEK) inhibitor trametinib was carried out, resulting in an increased clinical benefit (Flaherty et al. 2012; Heidorn et al. 2010).

\subsubsection{Therapy resistance}

To this date several conventional chemotherapeutic drugs such as dacarbazine or its derivative temozolomide have been tested in melanoma treatment, impairing cell division of tumor cells by methylating guanine. However, these 
treatments resulted in a low tumor response rate (below $20 \%$ ), indicating an almost universal chemoresistance of melanoma cells (Kreiseder et al. 2015).

The situation initially improved by targeted therapeutics, such as the BRAF ${ }^{V 600 E}$ inhibitors dabrafenib and vemurafenib, with an overall response rate of about $48 \%$ (Lo and Fisher 2014). Yet, over 80\% of initially treatment-responsive patients showed a disease progression within 12 months. Causative mechanisms of resistance include the aforementioned reactivation of the MAPK-pathway (Abildgaard and Guldberg 2015; Bucheit and Davies 2014).

The very aggressive and chemoresistant growth pattern of melanoma cells includes a myriad of intrinsic and extrinsic survival features concerning apoptosis. A main pathway involved in intrinsic apoptosis is the apoptotic protease activating factor $1 /$ Caspase-9 (Apaf-1/Casp9) mitochondrial pathway, which shows several alterations of anti-apoptotic factors in melanoma cells. Extrinsic apoptosis is mainly mediated by the death receptor pathway, which includes the binding of cytokines such as tumor necrosis factor-alpha (TNF- $\alpha$ ), TNF-related apoptosis-inducing ligand (TRAIL), or Fas ligand (FasL) to their receptors in the plasma membrane of the target cell. This pathway is activated by mediators of cellular immunity, but also as a response of cancer cells to drug therapy (Soengas and Lowe 2003).

Among others, a major player in the inhibition of intrinsic and extrinsic apoptosis in melanoma cells is the nuclear factor kappa-light-chain-enhancer of activated B cells (NF-KB) by influencing survival factors like B-cell lymphoma-extra-large (Bcl-xL), TNF receptor associated factors $1 / 2$ (TRAF1/2), FLICE-like inhibitory protein (cFLIP), and others (Amiri and Richmond 2005; Soengas and Lowe 2003). Accordingly, NF-KB is constitutively active in melanoma cells, which is caused by underlying gene alterations and autocrine mechanisms. Hence, it was shown that $K$-Ras and BRAF mutations indirectly activate NF-KB including the MAPKpathway. This signaling pathway also influences an autocrine G-protein-coupled receptors (GPCR) mediated system for constant NF-KB activation (Ueda and Richmond 2006).

\subsection{Transcription factor NF-KB}

Over thirty years ago a protein enhancing the transcription of immunoglobulin $\mathrm{K}$ light chains was identified in B cells by Sen and Baltimore. Accordingly, this 
protein was called "nuclear factor kappa-light-chain-enhancer of activated B cells", abbreviated NF-KB (Sen and Baltimore 1986). NF-KB is crucial for cell survival and growth, cell differentiation, inflammation and adhesion, implicating a key role in tumor initiation, promotion, angiogenesis, invasion, and metastasis (Bharti and Aggarwal 2002).

\subsubsection{Subunits and activation of NF-KB}

The transcription factor NF-KB is comprised of five subunits, which are divided into two subfamilies: The Rel subfamily including subunits c-Rel, RelA/p65 and RelB, and the NF-KB subfamily including subunits $p 50$ and $p 52$ with their inactive precursor forms p105 and p100. Accompanied with different desoxyribonuclein acid (DNA) and DNA-sequence binding affinities, all of these subunits form homo- or heterodimers with each other except for the subunit RelB, which is only able to form heterodimers (Gilmore 2006). To control activation of NF-kB, inhibitory proteins of the IкB family (e. g. ІкB- $\alpha$, ІкB- $\beta$, ІкB- $\varepsilon$ ) interact with NF-кB dimers (Adhikari et al. 2007).

Depending on the respective ligands binding to cell surface receptors, there are two major signal transduction pathways of NF-KB: the canonical/classical pathway and the non-canonical/alternative pathway. Among numerous activators, the canonical pathway is mainly activated via ligand/cell surface receptor interaction of the tumor necrosis factor receptor (TNFR) superfamily. This interaction leads to phosphorylation and activation of the IKB kinase complex (IKK). The IKK is also comprised of the catalytic kinase subunits IKK $\alpha$ and IKK $\beta$ and the NF-KB essential modulator (NEMO). Subsequently, the IKK complex phosphorylates and ubiquitinylates IKB, thus leading to proteasomal degradation. Therefore, liberated complexes mainly comprised of RelA/p50 or c-Rel/p50 can translocate to the nucleus and bind to their specific DNA target sequences enhancing transcription (Figure 2). Against the canonical pathway, the non-canonical pathway is activated by distinct receptor signals such as CD40 and lymphotoxin, predominantly concerning p52/RelB complexes. The receptor signal activates the NF-KB-inducing kinase (NIK), which then phosphorylates an IKK complex comprised of two IKKa subunits. As a result of such activation, the IKK $\alpha$ dimer activates the p100/RelB complex by processing the inactive form p100 to active p52. Subsequently, the p52/RelB complex is able to translocate to the nucleus (Fullard et al. 2012; Gilmore 2006). 

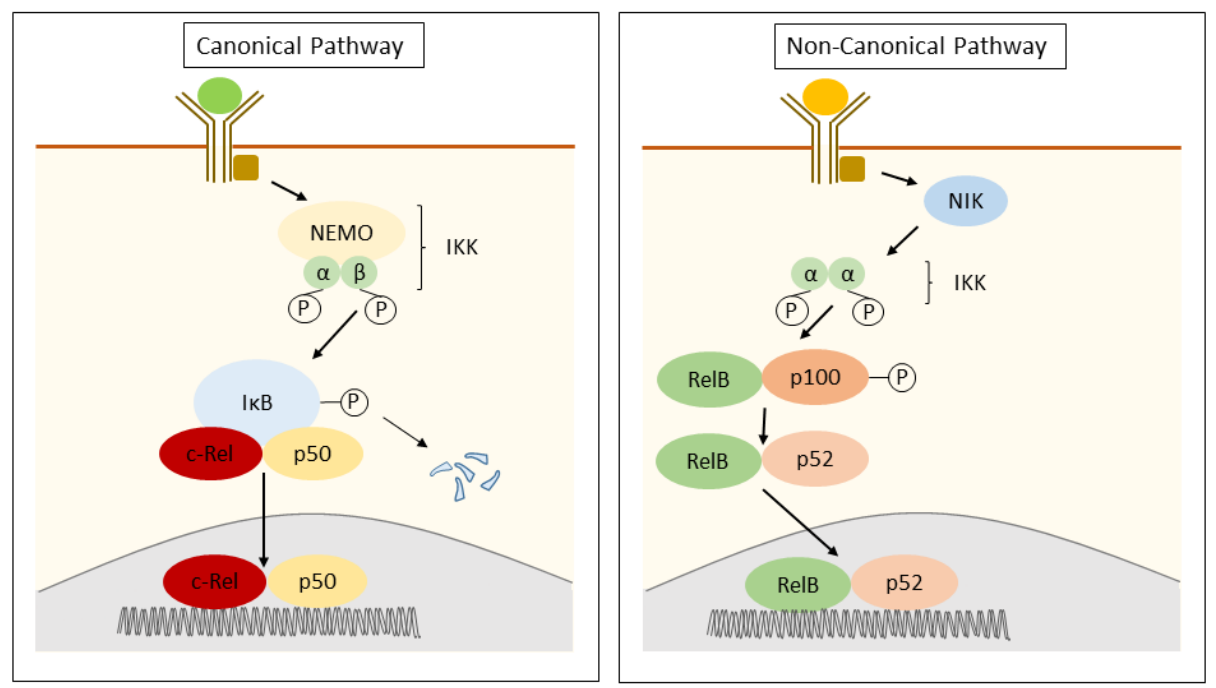

Figure 2: Scheme of typical NF-KB signal transduction pathways (adapted from Gilmore 2006).

The canonical/classical pathway is mainly activated by ligands of the TNFR superfamily, as depicted on the left side. The ligand/cell surface receptor interaction mobilizes an adaptor protein, which phosphorylates and activates an IKB kinase complex (IKK). Thereafter, the IKK complex phosphorylates and ubiquitinylates $1 \mathrm{~K} B$ inducing its proteasomal degradation. Then, the liberated complex of subunits c-Rel and p50 can translocate to the nucleus and bind to their specific DNA target sequences enhancing transcription. The non-canonical pathway is mainly activated by distinct receptor signals stimulated by CD40 and lymphotoxin, as depicted on the right side. These signals predominantly concern p52/RelB complexes and activate the NF-KBinducing kinase (NIK), which phosphorylates an IKK complex. Thereby, the IKK activates the $\mathrm{p} 100 /$ RelB complex by processing the inactive $\mathrm{p} 100$ to its active form $\mathrm{p} 52$. Now liberated, the p52/RelB complex translocates to its DNA sequences in the nucleus.

\subsubsection{NF-KB in epidermal cells}

Several studies on keratinocytes have shown that NF-KB is an essential regulator of skin homeostasis. In detail, the functional blockade of NF-KB led to a hyperplastic transgenic murine epidermis and an increase of proliferating human keratinocytes in vitro (Seitz et al. 1998). Further investigations revealed a growth inhibitory function of NF-KB by inducing cell cycle arrest in normal human keratinocytes (Seitz et al. 2000a). Furthermore, progressive epidermal dysplasia and development of squamous cell carcinoma (SCC) were observed after inhibition of NF-KB, thereby signaling $\mathrm{IKB}-\alpha$ in transgenic mice (van Hogerlinden et al. 2004). Recent data suggest that NF-KB inhibition causes a TNFR type 1-dependent chronic inflammation and additional growth of keratinocytes and may be involved in SCC development (Sur et al. 2008). 
Besides the anti-proliferative role of NF-KB in epidermal cells, NF-KB is also a main regulator of cell death in normal human epidermal cells by enhancing the expression of anti-apoptotic proteins like TRAF1, TRAF2 and the inhibitor of apoptosis (IAP) proteins C-IAP1 and c-IAP2 (Seitz et al. 2000b). In further investigations it was demonstrated by Diessenbacher et al. that inhibition of NFKB leads in HaCaT keratinocytes to TNF-induced apoptosis widely independent of c-IAP2. Nevertheless, NF-KB inhibition showed no effect on TRAIL-induced apoptosis (Diessenbacher et al. 2008).

Taken together, NF-KB acts as a major player of cell cycle progression and apoptosis in concert with numerous co-influencing and regulating proteins in epidermal cells.

\subsubsection{NF-KB in chemotherapy}

Interestingly, it was shown in many cell types that gamma irradiation and various chemotherapeutic agents such as doxorubicin, cisplatin, and etoposide activate a NF-KB-induced expression of pro-survival genes (Pahl 1999; Prasad et al. 1994; Wang et al. 1999). In contrast, several NF-KB inhibitors, which interfere with the NF-KB activation pathway, were shown to increase tumor susceptibility to chemotherapy in melanoma (Amiri and Richmond 2005). For example, the NEMO-binding domain (NBD) peptide reduced tumor growth based on increased apoptosis and growth arrest (Madonna et al. 2012). Furthermore, increased tumor susceptibility to chemotherapy was demonstrated by treating melanoma cell injected mice with the IKK $\beta$ inhibitor KINK-1 and doxorubicin or camptothecin (Schon et al. 2008). Additionally, doxorubicin-induced activation of NF-KB was strongly reduced by the use of the IKK $\beta$ kinase inhibitor (KINK-1; kinase inhibitor of nuclear factor-kappaB-1) leading to increased apoptosis (Pletz et al. 2012).

Considering the complex modulation of NF-KB activation by numerous pathways, additional chemotherapeutical options were identified (Amiri and Richmond 2005). Interestingly, the phosphatidyl inositol-3 kinase (PI3K)/ Protein kinase $B(A K T)$ signaling pathway was shown to affect activation of NF-KB, while antagonizing PI3K and AKT decreased NF-KB activation (Gupta et al. 2010). Additionally, in a glioma cell line cytokine-induced DNA binding and transcriptional activities of NF-KB were inhibited by transfection with a natural 
antagonist of the PI3K-pathway (Koul et al. 2001). Furthermore, the substantial role of the PI3K/AKT pathway in cell cycle control and cell proliferation in melanoma cells was demonstrated by Schneider et al.. Selective inhibition using the novel PI3K inhibitor, BAY 80-6946, led to melanoma cell growth inhibition in vitro and in vivo by G0/G1 phase shift (Schneider et al. 2014).

In regard of these findings, a selective inhibition of NF-KB activation may represent a new target for melanoma treatment. It appears that NF-KB inhibition primarily leads to an increased tumor susceptibility. However, selective NF-KB inhibition in concert with inhibition of pathways modulating activation of NF-KB constitutes further perspectives in the development of chemotherapeutical options in treatment of melanoma.

\subsubsection{Role of NF-kB subunit c-Rel}

In the past decades, it has become clear that each NF-KB subunit and each combination of NF-KB subunits have their own specific biological functions (Gilmore 2006). Thus, c-Rel was described as being involved in regulation of the immune system, different types of cancer, and other diseases such as liver fibrosis (Fullard et al. 2012).

Regarding epidermal cells, c-Rel deficient triple knockout mice (rela ${ }^{-1}$, c-reltnf $\alpha^{-1}$ mice) developed a thinned epidermis with abnormal hair follicle formation during embryogenesis. The mutant basal keratinocytes were strikingly small and further showed a delay in G1 cell cycle progression. Surprisingly, skin grafting of the mutant epidermis led to a basal cell hyperplasia and inflammation (Gugasyan et al. 2004). Concomitantly, Fullard et al. have shown a reduced proliferation of keratinocytes in vitro and in vivo in c-rel-- mice, indicating a pro-proliferative role for c-Rel in the skin (Fullard et al. 2013).

Similarly, studies examining c-Rel down-regulation in human keratinocytes showed inhibited viability and proliferation. Increased apoptosis and a G2/M cell cycle delay with aberrant mitotic spindle formations were demonstrated, implying a substantial role for c-Rel in apoptosis and cell cycle regulation of human keratinocytes (Lorenz et al. 2014).

McNulty et al. investigated the expression of NF-KB subunits in human melanocytes of normal skin, compared to cells of benign intradermal nevus and 
cells of metastatic melanoma. Interestingly, it was shown that there was an increased c-Rel expression in melanoma cells compared to melanocytes derived from normal skin and nevus. Regarding the distributional pattern, c-Rel was mainly found in the cytoplasm while concomitantly, the expression of $I_{\kappa} B \varepsilon$, primarily regulating nuclear translocation of c-Rel, was elevated (McNulty et al. 2004).

Together, this implies a mainly pro-proliferative function of c-Rel in keratinocytes as well as in human melanocytes, suggesting a key role in melanoma progression.

\subsection{Cell cycle regulation and mitosis}

The development of malignant melanoma is a result of a homeostatic imbalance in the skin, caused by a number of components in the skin that influence tumor development. A major disturbance comprises cell cycle dysregulation, leading to continuous cell proliferation (Satyamoorthy and Herlyn 2002). In this respect, cell cycle regulation has a critical influence on the transformation of melanocytes and is one central factor in melanoma progression (Piepkorn 2014).

The cell cycle is controlled by cyclins and cyclin-dependent kinases - a family of proteins controlling progression to the next cell cycle phase. Alterations in this control system are caused by underlying gene mutations. In the past years, mutations in the cyclin-dependent kinase Inhibitor 2A locus (CDKN2A) were of special interest, elucidating important gene loci involved in cell cycle control (Piepkorn 2000).

Mutations in the CDKN2A locus cause a deficit of the cyclin-dependent kinase 4 (CDK4) inhibitors $\mathrm{p} 16^{\mathrm{INK} 4 \mathrm{a}}$ and $\mathrm{p} 14^{\mathrm{ARF}}$. This affects the signaling pathways involving the tumor suppressor p53 and the retinoblastoma (RB) protein. Thus, the loss of cyclin-dependent cell cycle control by p53 and RB results in an increased cell proliferation by unrestrained cell cycle progression (Regad 2013). Altogether, four phases of the cell cycle exist: The G0/G1-, S-, G2-, and M-phase. The G0 phase implies a state of quiescence, in which cells can reenter the cell cycle at G1-phase. In the G1 phase, cells prepare for DNA replication before entering the following DNA duplicating S-phase, while cells grow and double 
their mass of proteins and organelles as needed for mitosis in the G2 phase (Walczak et al. 2010).

The chronological sequence of mitosis/M-phase can be subdivided into pro-, prometa-, meta-, ana-, and telophase. In prophase, instability of microtubules increases after chromosome condensation. A dynamic microtubule array (aster) assembles around the duplicated centrosomes. The centrosomes separate to form the two spindle poles. Interactions between the microtubule array and the minus- and plus-end-directed microtubule-dependent motor proteins lead to self-assembly of the bipolar spindle complex. In prometaphase, the breakdown of the nuclear envelope follows, which enables the kinetochores on the condensed chromosomes to bind to the microtubules from each spindle pole, subsequently arranging the chromosomes centered in between both spindle poles in metaphase (Alberts et al. 2002; Duro and Marston 2015).

To prevent a premature entry into the next mitotic phase, the integrity of the microtubule attachments to kinetochores is controlled by proteins of the spindle assembly checkpoint (SAC). This checkpoint is activated by improperly attached kinetochores, detected by proteins of the mitotic checkpoint complex (MCC) including CDC20, budding uninhibited by benzimidazole (BubR1), Bub3 and mitotic arrest deficient (MAD2). Also important for the regulation of kinetochore assembly are the proteins Aurora B, inner centromere protein (INCENP), Borealin, and Survivin, which form the chromosome passenger complex (CPC) (Lara-Gonzalez et al. 2012). After cells have lingered in mitotic arrest for hours, they either initiate cell death during mitosis or they exit mitosis by slipping into G1-phase in an aneuploid or tetraploid state. There, they either die because of their tetraploid state or they enter the next G1 phase with an aberrant chromosome content (Huang et al. 2009).

However, in metaphase with integer microtubule attachments to kinetochores, a linkage holding sister chromatids together is cleaved by proteolysis, which enables the chromosomes to move to the opposite poles in anaphase (Figure 3). Finally, the chromosomes decondense and rebuild a nucleus in telophase (Alberts et al. 2002; Deep and Agarwal 2008).

About $70 \%$ of cancer cells of various tissue types showed an increased rate of chromosome mis-segregations and aneuploidy (Cimini 2008; Weaver and 
Cleveland 2006). This phenomenon is called chromosomal instability (CIN) and represents a specific attribute of cancer. In comparison of CIN in melanocytes and melanoma cells, melanoma cells showed a remarkably increased CIN rate and thus suggesting a substantial role in development and progression of melanoma (Dabas et al. 2012). 


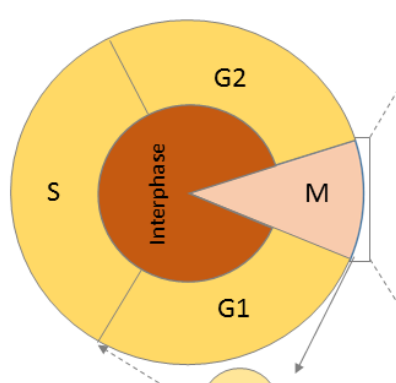

GO

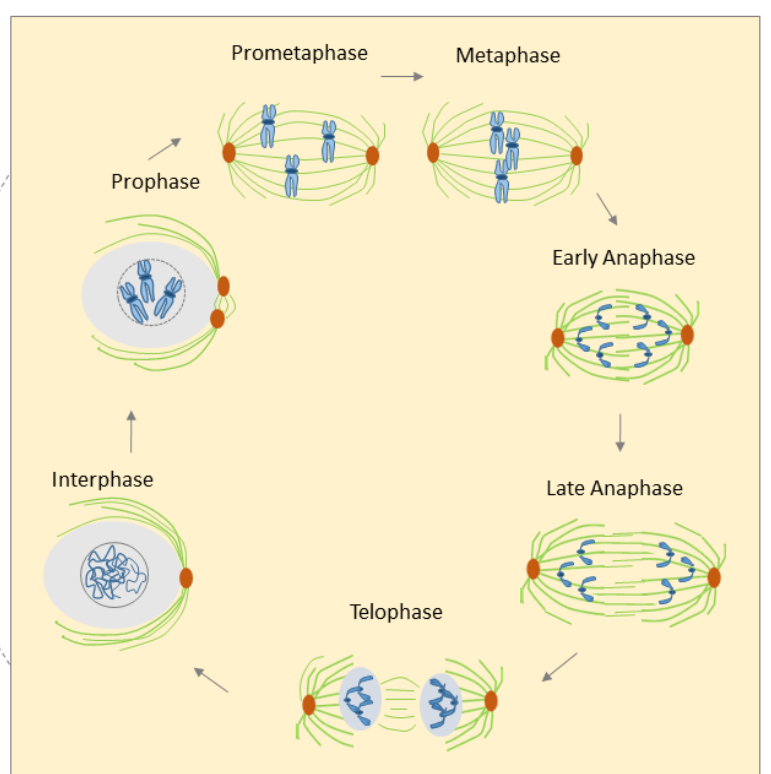

Figure 3: Schematic representation of the cell cycle phases and mitosis (adapted from Walczak et al. 2010).

The cell cycle is divided in G0/G1-, S-, G2-, and M-phase. The G1-phase implies preparation of cells for DNA replication before entering the following DNA duplicating S-phase. After S-phase, cells grow and double their mass of proteins and organelles in G2-phase. Thereafter, mitosis starts with chromosome condensation and an increase of instability of microtubules in prophase. A dynamic microtubule array assembles around the duplicated centrosomes to form the two spindle poles, followed by the breakdown of the nuclear envelope. Subsequently, the kinetochore microtubules pull each duplicated chromosome towards the spindle equator. In early anaphase, a linkage holding sister chromatids together is cleaved by proteolysis, which enables the chromosomes to move to the opposite poles. In late anaphase, the two spindle poles move apart. Subsequently, chromosome decondensation and rebuilding of a nucleus on the surface of each group of chromosomes follow during the telophase. 


\subsection{Aim of this study}

The transcription factor NF-KB is essential for cell proliferation, apoptosis, and immune responses. Thus, NF-kB plays also a substantial role in tumor initiation, tumor promotion, tumor invasion, and metastasis in different cell types (Bharti and Aggarwal, 2002). In regards to malignant melanoma, an increased NF-KB activity in dysplastic nevi and lesions of human melanoma was demonstrated by in vitro and in vivo studies in comparison with human nevi or melanocytes in normal skin (Ueda and Richmond 2006).

Indeed, little is known about the distinct functions of NF-KB subunits in melanoma cells, especially about subunit c-Rel so far. Studies by McNulty et al. revealed an elevated c-Rel expression in melanoma cells compared to normal skin and nevus cells (McNulty et al. 2004), implicating an uninvestigated role in tumor development and progression of malignant melanoma.

To investigate the impacts of c-Rel on melanoma growth and progression in more detail, seven different human melanoma cell lines were used, those of which derived from primary tumor or metastasis, respectively. Functional consequences of c-Rel down-regulation regarding cell proliferation, apoptosis, and cell cycle phase distribution or mitosis were studied in cell lines A375 and LOX by siRNA knockdown. 


\section{Material and Methods}

\subsection{Materials}

Table 1: List of laboratory equipment

Laboratory equipment

Company

Acetic acid

Carl Roth, Karlsruhe,

Germany

Appliskan Multimode

Thermo Fisher

Microplate Reader

Scientific, Waltham, MA,

USA

Autoclave

Sanyo, Moriguchi, Japan

BD FACSCanto II

BD Biosciences,

Franklin Lakes, NJ, USA

Cary 50 Micro-Volume

TrayCell Kit

Hellma, Müllheim,

Germany

Centrifuge Megafuge 1.0

Heraeus, Hanau,

Germany

Centrifuge Multifuge 1S-R

Heraeus, Hanau,

Germany

Centrifuge Pico 17

Heraeus, Hanau,

Germany

Centrifuge Rotina 35

Heraeus, Hanau,

Germany

$\mathrm{CO}_{2}$ Incubator HeraCell 150i

Heraeus, Hanau,

Germany

Cryo Freezing Container

Nalgene, Rocherster, NY USA

Double Distilled Water

Sartorius, Göttingen,

System Arium ${ }^{\circledR} 611 \mathrm{VF}$

Germany

Electrophoresis Power

Amersham

Supply-EPS 1001

Biosciences, Freiburg,

Germany

Galaxy Mini Centrifuge

VWR, Darmstadt,

Germany

Gel Imaging System U:Genius

Syngene, Cambridge, UK

Gradient Thermocycler

Eppendorf AG,

Mastercycler 
LAS-4000 Imaging System

Magnet Stirrer

Micro Scale ALC

Microscope Axiolmager M1

Microscope Axiovert 200

Microscope Axiovert 40C

Microwave Micromat

MSI Minishaker

pH-Meter FE20-Five easy ${ }^{\top \mathrm{M}}$

Pipette Set: 1,000, 100 and

$10 \mu \mathrm{l}$

PowerPac Basic

PowerPack P25

Refrigerated Centrifuge

5417R

Rocking Platform Polymax

1040

Scale Vicon

See-Saw Rocker SSL4

Spectrometer Genesys 10Bio

Sprout Microcentrifuge

Sterile Bench

Sub-Cell GT

Thermal Mixer ThermoStat

Plus

Trans-Blot SD Semi-Dry

Transfer Cell
Fujifilm, Tokio, Japan

VWR, Darmstadt,

Germany

Acculab, Göttingen, Germany

Zeiss, Jena, Germany

Zeiss, Jena, Germany

Zeiss, Jena, Germany

AEG, Nürnberg, Germany

IKA, Staufen, Germany

Mettler Toledo,

Greifensee, Switzerland

Eppendorf AG,

Hamburg, Germany

Bio-Rad, München,

Germany

Biometra, Göttingen,

Germany

Eppendorf AG,

Hamburg, Germany

Heidolph, Schwabach,

Germany

Acculab, Göttingen,

Germany

Stuart, Staffordshire, UK

Thermo Fisher

Scientific, Waltham, MA,

USA

Biozym Scientific, Hessisch Oldendorf, Germany

Heraeus, Hanau, Germany

Bio-Rad, München, Germany

Eppendorf AG,

Hamburg, Germany

Bio-Rad, München,

Germany 
Vertical Electrophoresis

System- Mini-

PROTEAN ${ }^{\circledR}$ TetraCell

Vortex L46

Water Bath

Table 2: List of disposable/re-usable material

Disposable/Re-usable

Material

6-Well Plates

8-Chamber CultureSlides

96-Well Plates, Flat Bottom

Cell Culture Flask $75 \mathrm{~cm}^{2}$

Cell Scrapers

Chromatography Paper

Whatman $^{\mathrm{TM}}$

Coverglasses, $24 \times 60 \mathrm{~mm}$

Cryo Vials Cryo.S

Falcon Tubes $15 \mathrm{ml}, 50 \mathrm{ml}$

Filter Pipette Tips for PCR

epT.I.P.S. ${ }^{\circledR}$

Filter Pipette Tips for RNA

TipOne

Freezing Tubes Cryo.S

HiBind RNA spin column

Needle Microlance 3
Bio-Rad, München,

Germany

Labinco, Breda,

Netherlands

Memmert, schwabach,

Germany

\section{Company}

Greiner Bio One,

Kremsmünster, Austria

BD Biosciences, Franklin

Lakes, NJ, USA

Greiner Bio One,

Kremsmünster, Austria

Greiner Bio One,

Kremsmünster, Austria

Sarstedt, Nümbrecht,

Germany

GE Healthcare, Chalfont

St Giles, UK

Menzel-Gläser,

Braunschweig, Germany

Greiner Bio One,

Kremsmünster, Austria

Greiner Bio One,

Kremsmünster, Austria

Eppendorf AG,

Hamburg, Germany

Starlab, Hamburg,

Germany

Greiner Bio One,

Kremsmünster, Austria

Omega Bio-Tek, Norcross, GA, USA

BD Biosciences, Franklin Lakes, NJ, USA 
Nitrocellulose Membrane

Neubauer chamber

Parafilm

PCR Reaction Tubes, $0.2 \mathrm{ml}$

Pipette Tips $10 \mu \mathrm{l}, 200 \mu \mathrm{l}$, $1,000 \mu \mathrm{l}$

Pipette epT.I.P.S. ${ }^{\circledR}$ Standard $10 \mathrm{ml}$

Plastic Cuvettes

Plastic Pipettes $5 \mathrm{ml}, 10 \mathrm{ml}$, $25 \mathrm{ml}$

Polystyrene Round Bottom

Tube, $5 \mathrm{ml}$

Reaction Cups $2 \mathrm{ml}, 1.5 \mathrm{ml}$ and $0.5 \mathrm{ml}$

Injekt-F $1 \mathrm{ml}$

TechnoCut Scalpel
Bio-Rad, München,

Germany

Assistant,

Sondheim/Rhön, Germany

American National

Can Co, Shelbyville, TN,

USA

Biozym Scientific, Hessisch Oldendorf, Germany

Starlab, Hamburg,

Germany

Eppendorf AG,

Hamburg, Germany

Sarstedt, Nümbrecht, Germany

Sarstedt, Nümbrecht, Germany

BD Falcon, Corning, NY, USA

Eppendorf AG, Hamburg, Germany

B. Braun, Melsungen, Germany

HMD Healthcare, Horsham, UK

Table 3: List of reagents

\section{Reagents}

\section{Company}

4',6-Diamidino-2-

Sigma-Aldrich, St

phenylindole (DAPI)

Louis, MO, USA

$6 x$ Loading dye

Fermentas, Waltham,

7x Protease inhibitor cocktail MA, USA

Aceton

Roche, Basel, Suisse

Carl Roth, Karlsruhe, Germany

Acetic acid

Merck, Darmstadt, 
Acrylamide/ Bis-acrylamide, $30 \%$ solution

Ammonium persulfate (APS)

Bovine serum albumin (BSA)

Bradford reagent

Bromophenol blue

Dimethyl sulfoxide (DMSO)

Dithiothreitol (DTT)

dNTP mix, 10 mM

Ethanol

Ethylenediaminetetraacetic acid (EDTA)

Fluorescence mounting medium

GelRed nucleic acid gel stain, 10,000x

Generuler 100 bp Plus

Glycerol

Glycine

Hydrochloric acid ( $\mathrm{HCl})$

Hydrogen peroxide $\left(\mathrm{H}_{2} \mathrm{O}_{2}\right)$

LE Agarose

Lipofectamine 2000

Luminol
Bio-Rad, München,

Germany

Gibco BRL, Carlsbad, CA, USA

Carl Roth, Karlsruhe, Germany

Bio-Rad, München, Germany

Sigma-Aldrich, st. Louis, MO, USA

Sigma-Aldrich, St. Louis, MO, USA

Carl Roth, Karlsruhe, Germany

Fermentas, Waltham, MA, USA

Carl Roth, Karlsruhe, Germany

Carl Roth, Karlsruhe, Germany

Dako, Hamburg,

Germany

Biotium, Hayward, CA, USA

Thermo Fisher

Scientific, Waltham, MA, USA

Carl Roth, Karlsruhe, Germany

Serva, Heidelberg, Germany

Carl Roth, Karlsruhe, Germany

Carl Roth, Karlsruhe, Germany

Biozym Scientific, Hessisch Oldendorf, Germany

Invitrogen, Karlsruhe, Germany

Sigma-Aldrich, St. Louis, MO, USA 
Magnesium chloride $\left(\mathrm{MgCl}_{2}\right)$

Methanol

Mycoplasma-Off

Non-fat dry milk (NFDM)

PageRuler prestained protein ladder

p-Coumaric acid

Ponceau S

Potassium chloride $(\mathrm{KCl})$

Potassium dihydrogen

phosphate $\left(\mathrm{KH}_{2} \mathrm{PO}_{4}\right)$

Potassium hydroxide $(\mathrm{KOH})$

Propidium iodide

Restore western blot stripping buffer

RNAse AWAY

Sodium azide $\left(\mathrm{NaN}_{3}\right)$

Sodium chloride $(\mathrm{NaCl})$

Sodium n-dodecyl sulfate

(SDS)

Sulfuric acid $\left(\mathrm{H}_{2} \mathrm{SO}_{4}\right)$

Tetramethylethylenediamine (TEMED)

\section{TRIS}

TRIS-hydrochloride acid
Carl Roth, Karlsruhe, Germany

Carl Roth, Karlsruhe, Germany

Minerva Biolabs, Berlin, Germany

Bio-Rad, München, Germany

Thermo Fisher

Scientific, Waltham, MA, USA

Sigma-Aldrich, St. Louis, MO, USA

Sigma-Aldrich, st. Louis, MO, USA

Carl Roth, Karlsruhe, Germany

Carl Roth, Karlsruhe, Germany

Carl Roth, Karlsruhe, Germany

Carl Roth, Karlsruhe, Germany

Thermo Fisher

Scientific, Waltham, MA, USA

Carl Roth, Karlsruhe, Germany

Sigma-Aldrich, st. Louis, MO, USA

Carl Roth, Karlsruhe, Germany

Carl Roth, Karlsruhe, Germany

Carl Roth, Karlsruhe, Germany

Carl Roth, Karlsruhe, Germany

Carl Roth, Karlsruhe, Germany

Carl Roth, Karlsruhe, Germany 
Triton X-100

Trypan blue

Tween-20

$\beta$-mercaptoethanol
Merck, Darmstadt,

Germany

Sigma-Aldrich, st. Louis, MO, USA

Carl Roth, Karlsruhe, Germany

Carl Roth, Karlsruhe, Germany

\section{Solutions and Buffers}

Basic Solution for Antibody Dilution (Immunofluorescence staining)

- $2.5 \%$ Triton-X

- PBS

FCS Blocking Solution (Immunofluorescence staining)

$-0.25 \%$ Triton-X

$-5 \%$ FCS

- PBS

\section{ECL Solution}

Solution 1

- 100 mM TRIS-HCl, pH 8.5

- $0.4 \mathrm{mM}$ p-coumaric acid

- $2.5 \mathrm{mM}$ luminol

Solution 2

- 100 mM TRIS-HCl, pH 8.5

$-0.018 \%$ hydrogen peroxide

Solution 1 and 2 were mixed 1:1 directly before usage.

\section{Ponceau S Staining Solution}

- $0.1 \%$ Ponceau S

- $5 \%$ Acetic acid

Running Buffer, 10x

- $1.92 \mathrm{M}$ glycine

- 250 mM TRIS

$-5 \%$ SDS

SDS Lysis Buffer

- $10 \%$ SDS

- 50 mM TRIS, pH 7.0

$-1 \%$ SDS

- $5 \% \beta$-mercaptoethanol

- $1 x$ protease inhibitor cocktail 
- $4 \%$ SDS

- $40 \%$ glycerol

- $0.07 \%$ bromophenol blue

TBE Buffer, 10x

- 890 mM TRIS

- 890 mM boric acid

- 20 mM EDTA, pH 8.0

TBS-T Buffer

- 10 MM TRIS

- 1 mM EDTA, pH 8.0

- $150 \mathrm{mM} \mathrm{NaCl}$

- 0.05 \% Tween 20

Transfer Buffer

- 48 mM TRIS

- 39 mM glycine

- $0.0375 \%$ SDS

- $20 \%$ methanol

Table 4: List of cell culture reagents

Cell culture reagents

Cryo-SFM

DMEM high Glucose (4.5 g/l)

FCS Superior

L-Glutamine (200 mM)

PBS-Phosphate-Buffered

Saline (10x) pH 7.4 10x

Penicillin/ Streptomycin (100x)

Trypsin-EDTA (1x)

$0.05 \% / 0.02 \%$ in PBS
Company

PromoCell, Heidelberg, Germany

PAA Laboratories, Pasching, Austria

Biochrom, Berlin, Germany

PAA Laboratories, Pasching,

Austria

PAA Laboratories, Pasching,

Austria

PAA Laboratories, Pasching,

Austria

PAA Laboratories, Pasching,

Austria

\section{Cell culture media}

\section{DMEM Growth Medium}

- $10 \%$ FCS

- $100 \mathrm{U} / \mathrm{ml}$ penicillin

- $100 \mu \mathrm{g} / \mathrm{ml}$ streptomycin

- $2 \mathrm{mM}$ L-glutamine 
DMEM Transfection Medium

- $10 \%$ FCS

- 2 mM L-glutamine

Table 5: Used primers

\begin{tabular}{|c|c|c|}
\hline \multicolumn{3}{|l|}{ Primers } \\
\hline Name & Sequence & Size \\
\hline REL (c-Rel) & $\begin{array}{l}\text { 5'-GGCCTCCTGACTGACTGACTG-3' } \\
\text { (forward) } \\
\text { 5'-ACGCATTCCCCTCTGCCTG-3' } \\
\text { (reverse) }\end{array}$ & 146bp \\
\hline GAPDH & $\begin{array}{l}\text { 5'-CTTTGGTATCGTGGAAGGACTC-3' } \\
\text { (forward) } \\
\text { 5'-TTCGTTGTCATACCAGGAAATG-3' } \\
\text { (reverse) }\end{array}$ & $451 \mathrm{bp}$ \\
\hline
\end{tabular}

REL primers were designed by V. Lorenz using PrimerBLAST (NCBI) and MWG Eurofins Operon for synthesis.

Table 6: List of utilized siRNA constructs

\begin{tabular}{|c|c|c|c|}
\hline \multicolumn{4}{|l|}{ SIRNA } \\
\hline Name & $\begin{array}{l}\text { Product } \\
\text { name }\end{array}$ & Target sequence & Company \\
\hline $\begin{array}{l}\text { control } \\
\text { siRNA }\end{array}$ & $\begin{array}{l}\text { AllStars } \\
\text { Neg. } \\
\text { Control } \\
\text { siRNA }\end{array}$ & Not announced & $\begin{array}{l}\text { Qiagen, } \\
\text { Hilden, } \\
\text { Germany }\end{array}$ \\
\hline $\begin{array}{l}\text { c-Rel } \\
\text { siRNA }\end{array}$ & Hs_REL_1 & $\begin{array}{l}5^{\prime}- \\
\text { CCGGTGCGTATAACC } \\
\text { CGTATA-3' }\end{array}$ & $\begin{array}{l}\text { Qiagen, } \\
\text { Hilden, } \\
\text { Germany }\end{array}$ \\
\hline
\end{tabular}


Table 7: List of used antibodies

\begin{tabular}{|c|c|c|c|}
\hline \multicolumn{4}{|l|}{ Antibodies } \\
\hline Name & Host & Dilution & Company \\
\hline \multicolumn{4}{|c|}{ Primary antibodies } \\
\hline Actin & mouse & $1: 1000$ & $\begin{array}{l}\text { Merck Millipore, } \\
\text { Billerica, MA, USA }\end{array}$ \\
\hline $\begin{array}{l}\text { Phospho- } \\
\text { Ser/Thr-pro, p- } \\
\text { MPM2 }\end{array}$ & mouse & $1: 100$ & $\begin{array}{l}\text { Merck Millipore, } \\
\text { Billerica, MA, USA }\end{array}$ \\
\hline $\mathrm{Bcl}-2$ & rabbit & $1: 1000$ & $\begin{array}{l}\text { Cell Signaling } \\
\text { Technology, } \\
\text { Danvers, MA, USA }\end{array}$ \\
\hline $\mathrm{BCl}-\mathrm{xL}$ & rabbit & $1: 1000$ & $\begin{array}{l}\text { Cell Signaling } \\
\text { Technology, } \\
\text { Danvers, MA, USA }\end{array}$ \\
\hline c-Rel & rabbit & $1: 500$ & $\begin{array}{l}\text { Cell Signaling } \\
\text { Technology, } \\
\text { Danvers, MA, USA }\end{array}$ \\
\hline GAPDH & rabbit & $1: 750$ & $\begin{array}{l}\text { Cell Signaling } \\
\text { Technology, } \\
\text { Danvers, MA, USA }\end{array}$ \\
\hline $\begin{array}{l}\text { Mouse IgG1 } \\
\text { isotype control }\end{array}$ & mouse & $1: 500$ & $\begin{array}{l}\text { Invitrogen, } \\
\text { Karlsruhe, Germany }\end{array}$ \\
\hline $\begin{array}{l}\text { Rabbit IgG } \\
\text { isotype Control }\end{array}$ & rabbit & $1: 1000$ & $\begin{array}{l}\text { Zymed, Karlsruhe, } \\
\text { Germany }\end{array}$ \\
\hline $\mathrm{Mcl}-1$ & rabbit & $1: 1000$ & $\begin{array}{l}\text { Cell Signaling } \\
\text { Technology, } \\
\text { Danvers, MA, USA }\end{array}$ \\
\hline Pericentrin & rabbit & $1: 1000$ & $\begin{array}{l}\text { Abcam, Cambridge, } \\
\text { UK }\end{array}$ \\
\hline $\begin{array}{l}\text { Phospho- } \\
\text { histone H3 }\end{array}$ & rabbit & $1: 1000$ & $\begin{array}{l}\text { Cell Signaling } \\
\text { Technology, } \\
\text { Danvers, MA, USA }\end{array}$ \\
\hline$\beta$-Tubulin & mouse & $1: 500$ & $\begin{array}{l}\text { Sigma-Aldrich, St. } \\
\text { Louis, MO, USA }\end{array}$ \\
\hline \multicolumn{4}{|c|}{ Secondary antibodies } \\
\hline $\begin{array}{l}\text { Alexa Fluor }^{\circledR} \\
555 \text { Goat Anti- } \\
\text { Rabbit IgG }(\mathrm{H}+\mathrm{L})\end{array}$ & goat & $1: 500$ & $\begin{array}{l}\text { Invitrogen, } \\
\text { Karlsruhe, Germany }\end{array}$ \\
\hline $\begin{array}{l}\text { Anti-mouse IgG } \\
(\mathrm{H}+\mathrm{L}), \mathrm{F}\left(\mathrm{ab} \mathrm{b}^{\prime}\right) 2 \\
\text { Fragment (Alexa }\end{array}$ & goat & $1: 300$ & $\begin{array}{l}\text { Cell Signaling } \\
\text { Technology, } \\
\text { Danvers, MA, USA }\end{array}$ \\
\hline
\end{tabular}




\begin{tabular}{|l|l|l|l|}
\hline $\begin{array}{l}\text { Fluor } \\
\text { Conjugate) }\end{array}$ & goat & $1: 2500$ & \\
\hline $\begin{array}{l}\text { Anti-Mouse IgG } \\
(\mathrm{H}+\mathrm{L}), \text { HRP } \\
\text { Conjugate }\end{array}$ & goat & $\begin{array}{l}\text { Promega, Fitchburg, } \\
\text { WI, USA }\end{array}$ \\
\hline $\begin{array}{l}\text { Anti-Rabbit IgG } \\
\text { (H+L), HRP } \\
\text { Conjugate }\end{array}$ & $1: 2500$ & $\begin{array}{l}\text { Promega, Fitchburg, } \\
\text { WI, USA }\end{array}$ \\
\hline
\end{tabular}

Table 8: List of used kits

Kits

Company

Cell Death Detection ELISA ${ }^{\text {PLUS }}$

Cell Proliferation ELISA, BrdU

E.Z.N.A. ${ }^{\circledR}$ Total RNA Kit I

First Strand cDNA Synthesis Kit

RNase-free DNase Set

CellTiter $96^{\circledR}$ Non-Radioactive Cell

Proliferation Assay (MTT)

Table 9: List of used softwares

\section{Software}

Axiovision Rel 4.7

LAS2000 Imaging System

Multi Gauge V3.2

Metamorph 6.3r2

Microsoft Office 2007

ImageJ $1.48 \mathrm{v}$

Adobe Illustrator CS6
Roche, Basel, Suisse

Roche, Basel, Suisse

Omega Bio-Tek, Norcross, GA,

USA

Fermentas, Waltham, MA, USA/

Thermo Fisher Scientific,

Waltham, MA, USA

Omega Bio-Tek, Norcross, GA, USA

Promega, Fitchburg, WI, USA

\section{Company}

Zeiss, Jena, Germany

Fujifilm, Tokio, Japan

Fujifilm, Tokio, Japan

Molecular Devices, Sunnyvale, CA, USA

Microsoft, Redmond, WA, USA

National Institute of Health, Bethesda, MD, USA

Adobe Systems, San José, CA, USA 
Table 10: List of used enzymes

Taq DNA polymerase

DNase I

RevertAid Reverse Transcriptase

RNase A

\subsection{Methods}

\subsubsection{Cell culture}

\subsubsection{Cultivation of melanoma cell lines}

To characterize the expression of c-Rel in different melanoma cell lines, the following seven immortalized cell lines were cultivated:

Table 11: List of used melanoma cell lines

\begin{tabular}{|l|l|}
\hline Cell line & Origin and attributes \\
\hline A375 & $\begin{array}{l}\text { Cell line is derived from a primary cutaneous tumor in } \\
1973 \text { (Giard et al. 1973). }\end{array}$ \\
\hline LOX & $\begin{array}{l}\text { Cell line is a xenograft, derived from an axillary lymph- } \\
\text { node metastasis of a malignant amelanotic melanoma in } \\
\text { athymic nude mice (Fodstad et al. 1988; Fodstad et al. } \\
1984 \text { ). }\end{array}$ \\
\hline Mel2a & $\begin{array}{l}\text { Cell line is derived from a metastasis of a malignant } \\
\text { melanoma in 1981 (Bruggen et al. 1981). }\end{array}$ \\
\hline MeWo & $\begin{array}{l}\text { Cell line is derived from a lymph-node metastasis of a } \\
\text { malignant melanoma in 1974 and contains melanin } \\
\text { pigments (Kodera and Bean 1975). }\end{array}$ \\
\hline MV3 & $\begin{array}{l}\text { Cell line is a xenograft and was derived from an axillary } \\
\text { lymph-node metastasis of a malignant amelanotic } \\
\text { melanoma in 1991 (Van Muijen et al. 1991). }\end{array}$ \\
\hline
\end{tabular}
USA

\author{
Omega Bio-Tek, Norcross, GA, \\ Thermo Fisher Scientific, \\ Waltham, MA, USA \\ Carl Roth, Karlsruhe, Germany \\ PEQLAB, Erlangen, Germany
}




\begin{tabular}{|l|l|}
\hline Sk-Mel-23 & $\begin{array}{l}\text { Cell line is derived from a metastasis of a malignant } \\
\text { melanoma in } 1980 \text { (Houghton et al. 1980). In contrast to } \\
\text { the other cell lines, cell pellets of Sk-Mel-23 show a } \\
\text { brownish color, suggesting heavy pigmentation of single } \\
\text { cells. }\end{array}$ \\
\hline
\end{tabular}

The different human melanoma cell lines A375, LOX, Mel2a, MeWo, MV3, MMNH and Sk-Mel-23 were cultivated in Dulbecco's Modified Eagle Growth Medium (DMEM) at $37{ }^{\circ} \mathrm{C}$ in a humidified atmosphere with $5 \% \mathrm{CO}_{2}$. They were passaged after 3 to 4 days at $70-90 \%$ cell confluency, depending on the different growth rates of the melanoma cell lines. All cell lines were routinely checked for mycoplasma contamination.

Before splitting, cells were washed with PBS and subsequently treated with 1.5 $\mathrm{ml}$ of trypsin for $3 \mathrm{~min}$ at $37^{\circ} \mathrm{C}$. Detaching of melanoma cells was supported by gently tapping the flask. By adding $5.5 \mathrm{ml}$ of DMEM, trypsin activity was inhibited and detaching was stopped. The harvested cells were then centrifuged at 1500 revolutions per minute $(\mathrm{rpm})$ for $3 \mathrm{~min}$ and re-suspended in $10 \mathrm{ml}$ DMEM afterwards. Cells were seeded in a new flask $\left(75 \mathrm{~cm}^{3}\right)$ containing $12 \mathrm{ml}$ of DMEM.

\subsubsection{Cell Counting}

Cell counting was performed using a Neubauer chamber. Melanoma cell suspensions were diluted 1:3 or 1:4 using trypan blue depending on the number of cells. Then, the Neubauer chamber was filled with $10 \mu$ l of cell suspension and vital cells were counted using a Axiovert $40 \mathrm{C}$ microscope.

\subsubsection{Cryopreservation}

For cryopreservation, cells were detached and re-suspended as described before in chapter 2.2.1.1 and counted in a Neubauer chamber to define the cell number. For a dilution of $1-2 \times 10^{6}$ cells per $\mathrm{ml}$ the cell suspension was centrifuged at $1500 \mathrm{rpm}$ for $3 \mathrm{~min}$ and re-suspended in Cryo-SFM freezing medium. The freezing medium-cell suspension was then aliquotted in $1 \mathrm{ml}$ per vial. The specific freezing vials were cooled down in a cell freezing container to $-80^{\circ} \mathrm{C}$ and stored in liquid nitrogen. To unthaw cryopreserved cells for following experiments, cells were slowly warmed up to $37^{\circ} \mathrm{C}$ and seeded in a T75 flask containing $12 \mathrm{ml}$ of DMEM. The growth media was changed $24 \mathrm{~h}$ after re- 
cultivation. The second passage after re-cultivation was used for further experiments.

\subsubsection{4 siRNA transfection}

Cells of the melanoma cell lines A375 and LOX were transiently transfected. Cells with the same passage number were used and cultured for a maximum of 8 passages. Cells were transfected by using Lipofectamine 2000 at $70-80 \%$ cell confluency. Primarily, Lipofectamine 2000, control siRNA and c-Rel siRNA were separately diluted in DMEM nullmedium at room temperature (RT) for $15 \mathrm{~min}$. Subsequently, Lipofectamine and siRNA dilutions were mixed and incubated at RT for exactly $15 \mathrm{~min}$. Meanwhile, cells were counted and a distinct number of cells per well transferred to the siRNA-lipofectamine suspension, depending on the size of the chosen growth surface. Finally, the control and siRNA was diluted to $100 \mathrm{nmol}$. DMEM transfection medium was replaced after $24 \mathrm{~h}$ and transfected cells used for further experiments after $72 \mathrm{~h}$.

\subsubsection{Growth curve generation}

Cell growth was characterized by imaging cells 0 h, 24 h, $48 \mathrm{~h}$ and $72 \mathrm{~h}$ after splitting or transfection, using the microscope Axiovert 200 equipped with a $10 x$ objective and the MetaMorph $6.3 \mathrm{r} 2$ software. Before microscopy at $0 \mathrm{~h}$ after seeding, cells were kept at $37^{\circ} \mathrm{C}$ for about 1 hour after seeding to attach to the growth surface. Prior to microscopy after $24 \mathrm{~h}, 48 \mathrm{~h}$ and $72 \mathrm{~h}$ cells were washed once with PBS and $12 \mathrm{ml}$ of growth medium was added. At a magnification of $10 x$, at least five microscopic fields of view per sample were photographed and quantitatively evaluated using the cell counter function of ImageJ $1.48 \mathrm{v}$.

\subsubsection{Protein extraction}

For protein extraction from melanoma cells, whole cell lysates were prepared. Cells were harvested by scraping and were pelleted at $850 \times \mathrm{g}$ at $4{ }^{\circ} \mathrm{C}$ for $10 \mathrm{~min}$. Afterwards, $100-200 \mu$ l of SDS lysis buffer was added and incubated at $95^{\circ} \mathrm{C}$ for $5 \mathrm{~min}$. Then, cell lysates were mechanically homogenized using a needle and a syringe. After centrifugation at $4{ }^{\circ} \mathrm{C}$, extracts of the whole cell lysates were transferred to a new reaction cup and were kept at $4{ }^{\circ} \mathrm{C}$ for further experiments. To determine the concentration of proteins, the Bradford assay was used. The absorbance of the protein concentration in $1 \mu \mathrm{l}$ of protein extracts mixed with 
$200 \mu \mathrm{l}$ Bradford reagent and $800 \mu \mathrm{l}$ double distilled water $\left(\mathrm{ddH}_{2} \mathrm{O}\right)$ was measured at $595 \mathrm{~nm}$ using a Genesys 10 Bio spectrometer. By comparing the extinction at $595 \mathrm{~nm}$ of distinct protein concentrations of the Bradford standard protein solutions to the extinctions of the samples, the concentration of protein extracts was determined.

\subsubsection{Western Blotting}

To examine the protein expression, 40-50 $\mu \mathrm{g}$ of whole cell lysate were mixed with $\mathrm{ddH}_{2} \mathrm{O}$ and $5 \times \mathrm{SDS}$ sample buffer to adjust equal protein concentrations in different samples to a total volume of $25 \mu \mathrm{l}$. Samples were heated at $95^{\circ} \mathrm{C}$ for 5 min and applied onto a $10 \%$ sodium dodecyl sulfate polyacrylamide gel electrophoresis (SDS-PAGE) gel together with a PageRuler prestained protein ladder. Electrophoresis was performed at $170 \mathrm{~V}$ until the sample buffer dye reached the lower end of the $10 \%$ SDS-PAGE gel.

To transfer the separated protein fractions onto a nitrocellulose membrane, the Trans-Blot SD Semi-Dry Transfer Cell was used. It is comprised of the gel and the nitrocellulose membrane enveloped by filter papers, which were soaked in cold transfer buffer. These layers were transferred to the semi-dry blotter and positioned between the anode and the cathode. An electric field of $150 \mathrm{~mA}$ was generated for $45 \mathrm{~min}$. To check whether proteins were successfully transferred, Ponceau S staining of the nitrocellulose membrane was used.

For the protein detection, specific antibodies were utilized. To prevent unspecific binding of antibodies, the membrane was blocked in $5 \%(w / v)$ dry milk in TBS-T for $1 \mathrm{~h}$. Then, the membrane was incubated with the specific antibody at $4{ }^{\circ} \mathrm{C}$ overnight. After three times washing for 15 min with TBS-T, a suitable HRP-labelled secondary antibody was added and incubated at RT for 1 h. Subsequently, the membrane was washed three times for 15 min TBS-T and incubated in ECL solution, which was mixed immediately before incubation. After $5 \mathrm{~min}$, the luminescence of the protein fractions was detected by using the LAS-4000 imaging system.

The relative protein amount was determined by densitometric analysis using Image $1.48 \mathrm{v}$. The pixel density of the detected bands was quantified and compared using GAPDH or actin as loading control. 


\subsubsection{RNA isolation}

For total RNA isolation, untransfected melanoma cells were detached by trypsin and transfected cells by using cell scrapers. Isolation was performed pursuant to the protocol of the E.Z.N.A. ${ }^{\mathrm{TM}}$ Total RNA Kit (TRK). First, cells were lysed by 350 $\mu$ or $700 \mu$ I TRK lysis buffer depending on size of the pellet and homogenized by using a syringe and a needle. Subsequently, $70 \%$ ethanol was added equally to the volume of the TRK lysis buffer. After transferring the suspension to a HiBind RNA spin column, it was washed once with RNA washing buffer I and centrifuged at $10,000 \times \mathrm{g}$ for $60 \mathrm{~s}$ at RT. Then, DNA was removed by adding RNase free DNase I and incubated for 15 min at RT. Subsequently three steps of washing with RNA washing buffers and followed by centrifugation at 10,000 $\times \mathrm{g}$ for $1 \mathrm{~min}$ at RT. After drying the column by centrifugation at $17000 \times \mathrm{g}$ at RT for $2 \mathrm{~min}$, RNA was diluted in diethylpyrocarbonate (DEPC) treated water by incubation and centrifugation at full speed at RT twice. Finally, the RNA concentration and purity were defined by measuring the absorbance of $1 \mu$ l of the RNA suspension at a wavelength of $260 \mathrm{~nm}$ and $280 \mathrm{~nm}$ using the Genesys 10 Bio spectrophotometer.

\subsection{6 cDNA synthesis}

For complementary DNA (cDNA) synthesis, the First Strand cDNA Synthesis Kit was used. $2 \mu \mathrm{g}$ of RNA suspension were used for the reverse transcriptionpolymerase chain reaction (RT-PCR). Depending on the measured total RNA concentration, the calculated sample volumes and nuclease free water were transferred into PCR reaction tubes to a total volume of $10 \mu \mathrm{l}$ per sample. After adding $1 \mu$ l of oligo(dT) ${ }_{18}$ primers binding the poly(A) tail of the mRNA, samples were heated up to $70^{\circ} \mathrm{C}$ for $5 \mathrm{~min}$ and afterwards cooled on ice. Subsequently, a mastermix consisting of $5 \mathrm{x}$ reaction buffer, $20 \mathrm{U}$ RiboLock RNase Inhibitor, $40 \mathrm{U}$ MMuLV reverse transcriptase and $1 \mathrm{mM}$ dNTP were added to the samples to reach a total volume of $20 \mu \mathrm{l}$. Thereafter, the RT-PCR was performed at $37^{\circ} \mathrm{C}$ for $1 \mathrm{~h}$ and stopped by keeping samples at $70^{\circ} \mathrm{C}$ for $5 \mathrm{~min}$. For further experiments, CDNA was stored at $-20^{\circ} \mathrm{C}$.

\subsubsection{PCR}

For polymerase chain reaction (PCR) of $1 \mu \mathrm{l}$ CDNA, the following components for a mastermix were used: 
Table 12: Concentrations of PCR components

\begin{tabular}{|ll|}
\hline Mastermix & \\
\hline Component & Concentration \\
Primer forward & $2.5 \mu \mathrm{l}(1 \mathrm{x})$ \\
Primer reverse & $1 \mu \mathrm{l}(0.4 \mu \mathrm{M})$ \\
dNTPs & $1 \mu \mathrm{l}(0.4 \mu \mathrm{M})$ \\
Taq-Polymerase & $1 \mu \mathrm{l}(0.4 \mu \mathrm{M})$ \\
dd $\mathrm{H}_{2} \mathrm{O}$ & $0.2 \mu \mathrm{l}(1 \mathrm{U})$ \\
\end{tabular}

Then, $24 \mu \mathrm{l}$ of the mastermix were added to $1 \mu \mathrm{l}$ of cDNA in PCR reaction tubes. For PCR, the Gradient Thermocycler Mastercycler with the following general cycling parameters was used:

Table 13: General cycling profile

\begin{tabular}{|l|l|l|l|l|}
\hline & Process & Temperature & $\begin{array}{l}\text { Time } \\
(\min )\end{array}$ & Cycles \\
\hline 1 & $\begin{array}{l}\text { Initial DNA } \\
\text { denaturation }\end{array}$ & $95{ }^{\circ} \mathrm{C}$ & 2 & 1 \\
\hline 2 & Denaturation & $95^{\circ} \mathrm{C}$ & 0.5 & \\
\hline 3 & Annealing & $60^{\circ} \mathrm{C}$ & 0.5 & $25-35$ \\
\hline 4 & Elongation & $72{ }^{\circ} \mathrm{C}$ & 0.75 & \\
\hline 5 & $\begin{array}{l}\text { Final } \\
\text { elongation }\end{array}$ & $72{ }^{\circ} \mathrm{C}$ & 5 & 1 \\
\hline
\end{tabular}

Thereafter, $5 \mu$ l of $6 x$ loading dye were added to $25 \mu$ l sample volume and of which $10 \mu \mathrm{l}$ were inserted in a polymerized $1.5 \%$ agarose gel provided with GelRed Nucleic Acid Gel stain. $3 \mu$ of Generuler 100 bp Plus served as a DNA 
standard ladder. Samples were separated at $140 \mathrm{~V}$ for $45-60 \mathrm{~min}$. Bands of PCR samples were imaged using the Gel Imaging System U:Genius.

\subsubsection{Assays}

For the following assays, cells were seeded in triplicates in 96 well plates. For that, $3.5 \times 10^{3}$ cells per well were transferred and transfected according to the standards as described in chapter 2.2.1.4.

\subsubsection{MTT cell viability assay}

To determine cell viability, 3-(4,5-dimethylthiazol-2-yl)-2,5-diphenyltetrazolium bromide (MTT) of the CellTiter $96^{\circledR}$ Non-Radioactive Cell Proliferation assay was used. Vital cells are capable of reducing the yellow dye MTT to insoluble, purple colored formazan. By measuring the absorbance, difference of cell viability can be analyzed. According to the manufacturer's protocol, $15 \mu \mathrm{l} /$ well of dye solution were pipetted. Afterwards, cells were incubated at $37^{\circ} \mathrm{C}$ in a humidified atmosphere with $5 \% \mathrm{CO}_{2}$ for $4 \mathrm{~h}$. Then, the reaction was stopped by pipetting $100 \mu \mathrm{l} /$ well of stop solution. Cells were incubated at $37^{\circ} \mathrm{C}$ overnight to avoid cristallisation. For evaluation, absorbance was measured at $570 \mathrm{~nm}$ and $630 \mathrm{~nm}$ as reference wavelength with the Appliskan Plate Reader the next day.

\subsubsection{BrdU cell proliferation assay}

Cell proliferation was analyzed by using the Cell Proliferation ELISA assay. The reagent bromodeoxyuridine (BrdU), functioning as an analogon of the nucleosid thymidine, can be taken up by vital cells and incorporated into DNA, when cells are synthesizing DNA during $S$ phase of the cell cycle. For detection of the incorporated BrdU, DNA has to be denaturized to provide binding of specific antibodies for BrdU. By means of a subsequent substrate reaction, the antibody bound to BrdU can be detected measuring the absorbance. Pursuant to the manufacturer's protocol, $100 \mathrm{nM}$ BrdU solution were pipetted $56 \mathrm{~h}$ after transfection and incubated for $16 \mathrm{~h} .72 \mathrm{~h}$ after transfection, cells were denaturized by adding $200 \mu \mathrm{l} /$ well of Fix/Denat solution and incubated at RT for $30 \mathrm{~min}$. After removing the solution, denaturized cells were incubated with 100 $\mu \mathrm{l} /$ well of Anti BrdU POD working solution, containing the specific antibodies at RT for $90 \mathrm{~min}$. Then, the plate was washed three times and treated with 100 $\mu \mathrm{l} /$ well of substrate solution. Finally after a sufficient color development, the 
reaction was stopped by transferring $100 \mu \mathrm{l} /$ well of stop solution and the absorbance was measured at $450 \mathrm{~nm}$ with the Appliskan Plate Reader.

\subsubsection{Apoptosis assay}

To detect apoptosis rate of cells, the Cell Death Detection ELISA ${ }^{\text {PLUs }}$ assay was used. This assay is based on the detection of apoptotic vesicles containing nucleosomes and histones, which are set free after lysis of cells. The content of the vesicles is bound by anti-histone-biotin and anti-DNA-POD antibodies according to the quantitative sandwich-enzyme-immunoassay-principle. After adding the substrate 2,2'-azino-bis(3-ethylbenzothiazoline-6-sulphonic acid) (ABTS), the enzyme horseradish peroxidase (HRP), conjugated to the antibodies, metabolizes the ABTS substrate and catalyzes a color development. Thereby, the apoptosis rate can be indirectly detected by measuring the absorbance. According to the manufacturer's standards, $72 \mathrm{~h}$ after transfection, cells were pelleted at $200 \times \mathrm{g}$ for $10 \mathrm{~min}$ and medium was removed. Subsequently, cells were incubated in $200 \mu \mathrm{l} /$ well of lysis buffer at RT for $30 \mathrm{~min}$. After centrifugation at $200 \times \mathrm{g}$ for $10 \mathrm{~min}, 20 \mu \mathrm{l}$ of the cell lysate suspension were pipetted into streptavidin coated wells. Thereafter, $80 \mu \mathrm{l} /$ well of immunoreagent containing anti-histone-biotin and anti-DNA-POD antibodies were transferred and incubated at RT for $2 \mathrm{~h}$. After removing the solution, wells were washed three times and $100 \mu \mathrm{l}$ of ABTS solution was added. The color reaction was supported by using a plate shaker and was stopped by adding 100 $\mu \mathrm{l} /$ well of ABTS stop solution after a sufficient color development. Finally, the absorbance of each sample was measured at $405 \mathrm{~nm}$ with the Appliskan Plate Reader. The measured data of the blank were subtracted from the measured data of the samples.

\subsubsection{FACS cell cycle analysis}

Fluorescence-activated cell sorting (FACS) allows a differentiation of cells by using certain fluorescent dyes or antibodies, causing different refractions of light. To determine cell cycle phases by detecting the DNA content of cells, the fluorescent dye propidium iodide, which binds to nucleic acids, was used. Additionally, the mitosis specific antibody anti-phospho-Ser/Thr-pro, mitotic protein monoclonal-2 ( $p$-MPM2) was used, to differentiate between cells in G2 phase and cells in $M$ phase. The antibody binds to phospho amino acidcontaining epitopes, expressed on over 50 proteins of $M$ phase eukaryotic cells. 
$72 \mathrm{~h}$ after transfection, cells were prepared by trypsinizing, pelletizing and resuspending in $500 \mu \mathrm{l}$ of PBS. Then, cells were treated with $3 \mathrm{ml}$ of ice-cold 100 $\%$ ethanol (EtOH), added very slowly. Thereafter, samples were prepared for subsequent FACS analysis or stored at $-20{ }^{\circ} \mathrm{C}$ for further experiments. For staining, EtOH was removed and cells were incubated in $500 \mu$ of $0.25 \%$ Triton$X$-PBS on ice for $15 \mathrm{~min}$. Thereafter, the solution was removed and cells were treated with MPM-2 antibody, diluted 1:100 in 1\% BSA-PBS-solution, at RT for $60 \mathrm{~min}$. Then, cells were washed with $100 \mu \mathrm{l}$ of $1 \%$ BSA-PBS-solution and $100 \mu \mathrm{l}$ of Alexa Fluor ${ }^{\circledR} 488$ Conjugate, diluted 1:300 in 1\% BSA-PBS-solution was added and incubated at RT in the dark for $30 \mathrm{~min}$. Subsequently, $500 \mu \mathrm{l}$ of 1:10 diluted RNase $A$ and 1:20 diluted propidium iodide in PBS were added and cells were incubated at RT in the dark for 30 min. Finally, cell solutions were vortexed directly before measuring with the BD FACS Canto II.

\subsubsection{Immunofluorescence}

\subsubsection{1 c-Rel}

To analyze c-Rel expression and its nucleic and cytoplasmic distribution, transfected cells were imaged by immunofluorescence using the primary c-Rel antibody. Nuclei were stained using 4',6-diamidino-2-phenylindole (DAPI). Therefore, $5 \times 10^{3}$ cells were seeded in 8-well culture slides for transfection. Then, cells were carefully washed with $500 \mu \mathrm{l} /$ well of $1 \mathrm{xPBS}$ at $4{ }^{\circ} \mathrm{C} 72 \mathrm{~h}$ after transfection. Thereafter, cells were fixed with $500 \mu \mathrm{l} /$ well of ice-cold $(100 \%)$ methanol for $5 \mathrm{~min}$. Subsequently, two steps of washing with $1 \mathrm{xPBS}\left(4^{\circ} \mathrm{C}\right)$ followed. After that, cells were incubated in immunofluorescence blocking solution at RT on a shaker for $60 \mathrm{~min}$. Then, the primary antibody anti-c-Rel as well as the rabbit IgG isotype control were diluted 1:300 in basic solution and $280 \mu \mathrm{l} /$ well were pipetted into wells for incubation at $4{ }^{\circ} \mathrm{C}$ on a shaker overnight. The next day, cells were washed with $1 x P B S\left(4^{\circ} \mathrm{C}\right)$ three times for 10 min each, before cells were consecutively treated with the secondary antibody Alexa Fluor $^{\circledR} 555$ Goat Anti-Rabbit IgG $(\mathrm{H}+\mathrm{L})$ (1:500) diluted in basic solution and incubated covered from light by aluminum foil at RT for $1 \mathrm{~h}$. After incubation, cells were washed three times as described previously and were dried for about $1 \mathrm{~min}$. Then, the cells were embedded and stained with DAPI, which was diluted 1:100 in $200 \mu \mathrm{l}$ of Fluorescence Mounting Medium (Dako). After preparing the culture slide for microscopy, cells were imaged using the color channels Texas 
Red and DAPI of the Zeiss microscope Axiolmager M1 and the software Axiovision Rel 4.7. Pictures (400x) were evaluated and digitally enhanced using Image $1.48 \mathrm{v}$.

\subsubsection{Mitotic spindle}

For analysis of mitosis, transfected cells were imaged by immunofluorescence staining the primary antibodies anti-pericentrin to visualize centrosomes and anti-tubulin for microtubules. Nuclei were stained using DAPI. For immunofluorescence, $5.5 \times 10^{3}$ cells were seeded in 8-well culture slides for transfection. $72 \mathrm{~h}$ after transfection, cells were carefully washed with 500 $\mu \mathrm{l} /$ well of 1 xPBS at $4{ }^{\circ} \mathrm{C}$. Thereafter, cells were fixed with $500 \mu \mathrm{l} /$ well of ice-cold (100\%) methanol for $5 \mathrm{~min}$, followed by two steps of washing with $1 \times \mathrm{PBS}\left(4^{\circ} \mathrm{C}\right)$. Subsequently, cells were incubated in immunofluorescence blocking solution at RT on a shaker for $60 \mathrm{~min}$. Afterwards, the first primary antibodies antipericentrin (anti mouse) respectively mouse IgG1 isotype control were diluted 1:1000 in basic solution and $280 \mu \mathrm{l} /$ well were pipetted. The cells were incubated at $4{ }^{\circ} \mathrm{C}$ on a shaker overnight. The next day, cells were washed with $1 \times \operatorname{PBS}\left(4^{\circ} \mathrm{C}\right)$ three times for $10 \mathrm{~min}$ each. Thereafter, cells were treated with the second primary antibodies anti-tubulin (anti-rabbit) and respectively rabbit IgG isotype control, which were diluted 1:500 in basic solution. Subsequently after washing with 1 XPBS $\left(4^{\circ} \mathrm{C}\right)$ three times for 10 min each, cells were consecutively treated with the secondary antibodies Alexa Fluor ${ }^{\circledast} 555$ Goat Anti-Rabbit IgG $(\mathrm{H}+\mathrm{L})$ (1:500) and Anti-mouse IgG $(\mathrm{H}+\mathrm{L}), \mathrm{F}\left(a b^{\prime}\right) 2$ Fragment (Alexa Fluor ${ }^{\circledR} 488$ Conjugate) (1:300) diluted in basic solution and incubated covered from light by aluminum foil at RT for $1 \mathrm{~h}$. After each incubation, cells were washed three times as described previously. Finally, the cells were embedded and stained with DAPI, diluted 1:100 in $200 \mu \mathrm{l}$ of Fluorescence Mounting Medium (Dako), and the culture slide was prepared for microscopy. Cells were imaged using the color channels Texas Red, FITC and DAPI of the Zeiss microscope Axiolmager M1 and the software Axiovision Rel 4.7. Pictures (200x) of at least 100 mitotic cells of each sample were taken and evaluated using ImageJ $1.48 \mathrm{v}$.

\subsubsection{Statistical evaluation}

In general, two-sided paired student's t-test was used to determine $p$ values. The statistical evaluation was supported by members of the center for 
informatics, statistics and epidemiology of the Georg-August-University in Göttingen. 


\section{Results}

\subsection{Characterization and c-Rel expression of melanoma cell lines}

In view of further describing the function of c-Rel in melanoma, seven melanoma cell lines were characterized regarding morphology, growth and c-Rel expression.

\subsubsection{Morphology and growth of melanoma cell lines}

On the single cell level, the seven melanoma cell lines A375, LOX, Mel2a, MeWo, MV3, MMNH and Sk-Mel-23 showed different morphology. The cell lines A375, LOX, MeWo, MV3 and MMNH showed a more epitheloid phenotype with formation of lamellipodia-like structures, whereas cell lines Mel2a and Sk-Mel23 showed a more mesenchymal-like, spindle-shaped morphology with formation of extensive pseudopodia (Figure 4A).

Qualitative evaluation of cell growth indicated cluster-like growth of A375, LOX, MV3, MeWo and MMNH, whereas Mel2a and Sk-Mel-23 showed rather singled and scattered growth pattern (Figure $4 \mathrm{~A}$ ).

Quantitative evaluation of cell growth was performed according to chapter 2.2.1.2 per field of view at a magnification of $10 x$. Initially, $0,75 \times 10^{6}$ cells were seeded per T75 flask for each cell line (Figure 4B). As soon as $48 \mathrm{~h}$ after seeding, cell lines displayed slight differences in growth patterns. At this point of time, MV3 showed the highest cell number per field of view (219 \pm 47 ), whereas MeWo

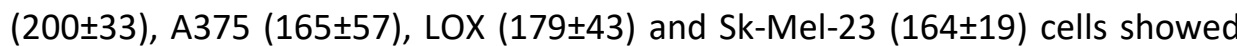
lower cell numbers. However, Mel2a already indicated the lowest growth rate $48 \mathrm{~h}$ after seeding with $129 \pm 22$ cells per field.

$72 \mathrm{~h}$ after seeding, MeWo showed the highest cell number of about $540 \pm 81$ cells per field of view. In comparison, growth of cell lines A375 (510 \pm 33 cells per field) was slightly reduced. Cell lines LOX ( $490 \pm 182$ cells per field) and MV3 (450 \pm 143 cells per field) showed a moderate growth, whereas Sk-Mel-23 $(300 \pm 104$ cells

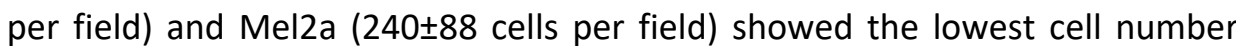
(Figure 4B). The growth curve of MMNH cells could not be evaluated due to a high amount of cell debris, which rendered cell counting impossible. Thus, clear differences of growth rates could be demonstrated within the observed 
timeframe indicating a rather exponential growth pattern of cell lines MeWo, A375, LOX and MV3 and a rather linear growth pattern of cell lines Mel2a and Sk-Mel-23 (Figure 4B). 
A
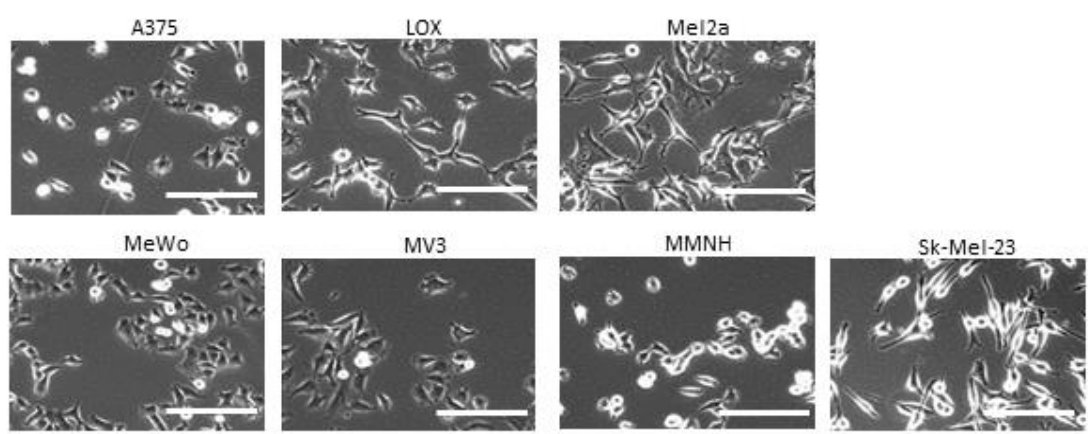

B

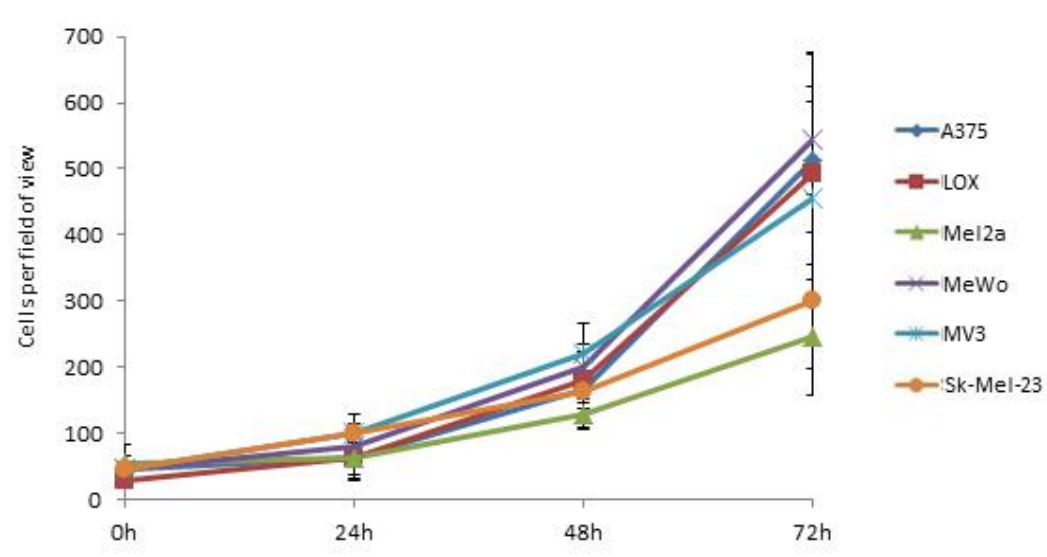

Figure 4: Melanoma cell lines show different phenotypes and growth rates.

(A) Phase contrast images (100x) of melanoma cell lines A375, LOX, Mel2a, MeWo, MV3, MMNH and Sk-Mel-23 24h after seeding. Bar=100 $\mu \mathrm{m}$ (B) Cell growth curves of melanoma cell lines A375, LOX, Mel2a, MeWo, MV3, MMNH and Sk-Mel-23. Mean of cell numbers of at least 5 microscopic fields $(100 \mathrm{x})$ is depicted for $0 \mathrm{~h}, 24 \mathrm{~h}, 48 \mathrm{~h}$ and $72 \mathrm{~h}$ after seeding. Error bars are \pm SD.

\subsection{2 mRNA and protein expression level of c-Rel}

To investigate whether c-Rel is expressed in the characterized melanoma cell lines and to which degree, analysis of c-Rel mRNA expression level was performed by semi-quantitative PCR. Moderate but similar c-Rel expression levels could be detected after 30 cycle counts in all cell lines. Additionally, western blotting of whole cell lysates was performed, showing different levels of c-Rel expression in all melanoma cell lines (Figure 5A). 
Furthermore, densitometric evaluation of relative c-Rel protein expression revealed strongest c-Rel expression in LOX cells. In relation to its expression level, A375 cells showed a slightly $(10 \%)$ decreased c-Rel expression. Similarly, c-Rel expression was lower in MeWo (20 \%), MMNH (30\%), Mel2a (40\%) and Sk-Mel-23 (40\%). Of all cell lines, MV3 showed the lowest c-Rel expression compared to LOX (60 \%) (Figure 5B-C). Additionally, subcellular (nucleic/cytoplasmatic) c-Rel expression was imaged in cell lines A375 and LOX by immunostaining. Both cell lines showed a more cytoplasmatic cellular distribution and additionally small nuclear speckles (Figure 5D).

Altogether, even though c-Rel mRNA expression was quite similar, protein expression differed between the seven melanoma cell lines. Of those, the cell lines with the highest c-Rel protein expression, A375 and LOX, were chosen for further studies on c-Rel function in melanoma. 
A

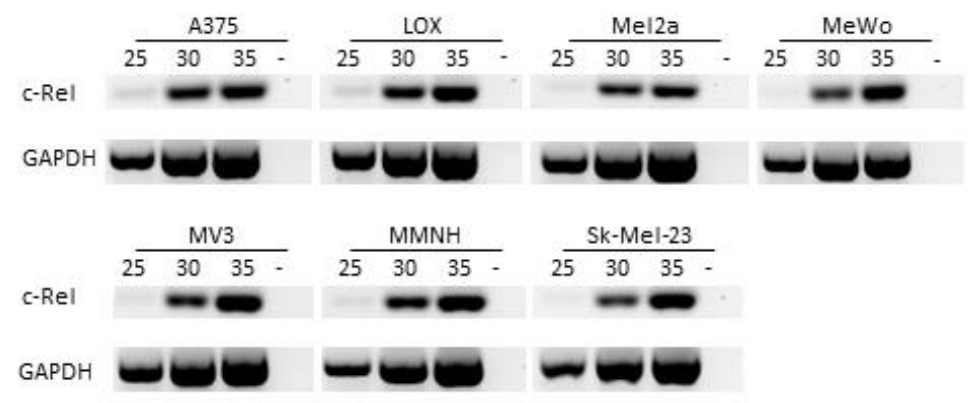

B

C

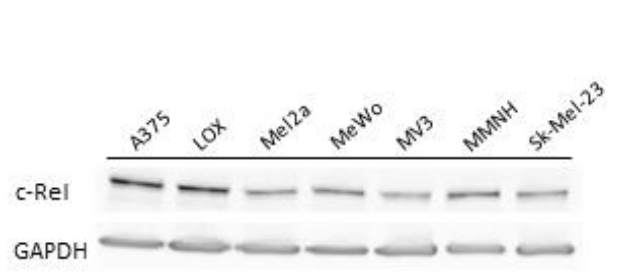

D

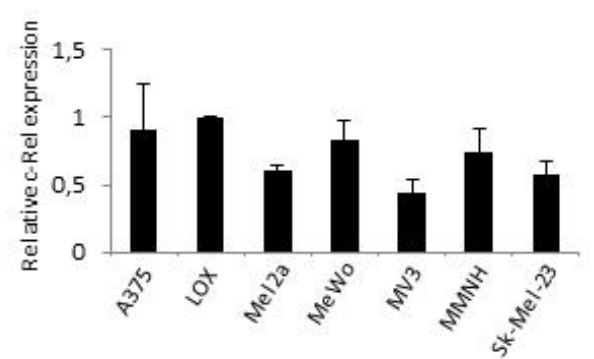

A375
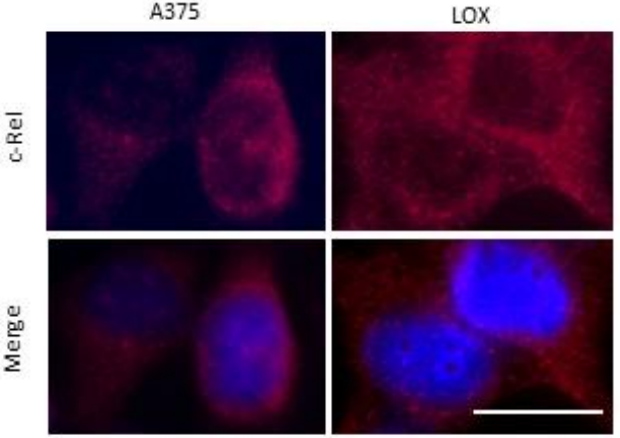

Figure 5: Melanoma cells have different levels of c-Rel expression.

(A) Semi-quantitative PCR with different cycle counts $(25,30,35)$ revealed similar c-Rel expression in cell lines A375 and LOX. GAPDH served as loading control. (-) indicates the negative control. One of three representative experiments is shown. (B) Western blotting of $50 \mu \mathrm{g}$ whole cell lysate showed varying c-Rel expression in seven melanoma cell lines. GAPDH served as loading control. One of three representative experiments is shown. (C) Densitometric evaluation of the relative c-Rel expression indicated the strongest expression of c-Rel in cell lines A375 and LOX. Evaluation was performed using ImageJ software. Mean of three independent experiments is shown, error bars are \pm SEM. (D) Immunostaining of cRel in A375 and LOX cells (400x). Cells were incubated with anti-rabbit secondary antibody conjugated with AlexaFluor 555. Nuclei were stained with DAPI, as depicted on the right side. Images were digitally enhanced. Bar $=20 \mu \mathrm{m}$.

\subsection{Efficient siRNA transfection and c-Rel down-regulation in cell lines A375 and LOX}

To investigate the function of c-Rel, the cell lines A375 and LOX with highest cRel expression were chosen for siRNA transfection. To determine optimal 
conditions for efficient siRNA transfection, the parameters siRNA concentration, lipofectamine concentration, number of cells, siRNA incubation time and cell confluence were optimized.

For c-Rel down-regulation in cell lines A375 and LOX, a c-Rel specific siRNA was used (SI00045570), which was shown to efficiently down-regulate c-Rel (Qiagen, Hilden, Germany). Cells were treated with $50 \mathrm{nmol}$ and $100 \mathrm{nmol}$ of c-Rel siRNA and western blotting was performed to test transfection efficacy. Both siRNA concentrations showed a mean c-Rel down-regulation of $50 \%$ (Figure A-B). 
A

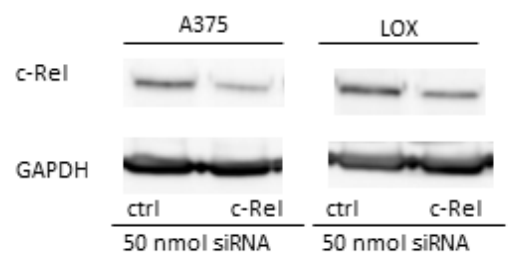

B

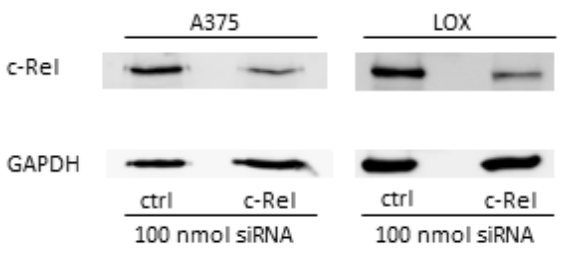

Figure 6: Efficient transfection and c-Rel down-regulation in A375 and LOX cells.

(A) Western blotting of $50 \mu \mathrm{g}$ whole cell lysate cells of melanoma cell lines A375 and LOX treated with $50 \mathrm{nmol}$ and (B) $100 \mathrm{nmol}$ of control siRNA (ctrl) and c-Rel siRNA (c-Rel) 72 hours after siRNA transfection. Mean c-Rel down-regulation of $50 \%$ by c-Rel siRNA transfection. GAPDH served as loading control. One of three independent experiments is shown.

Furthermore, comparing the portion of transfected cells by FACS analysis using different siRNA concentrations demonstrated the highest portions of viable transfected cells using high siRNA concentrations such as $100 \mathrm{nmol}$ (Figure 7AC). 
A
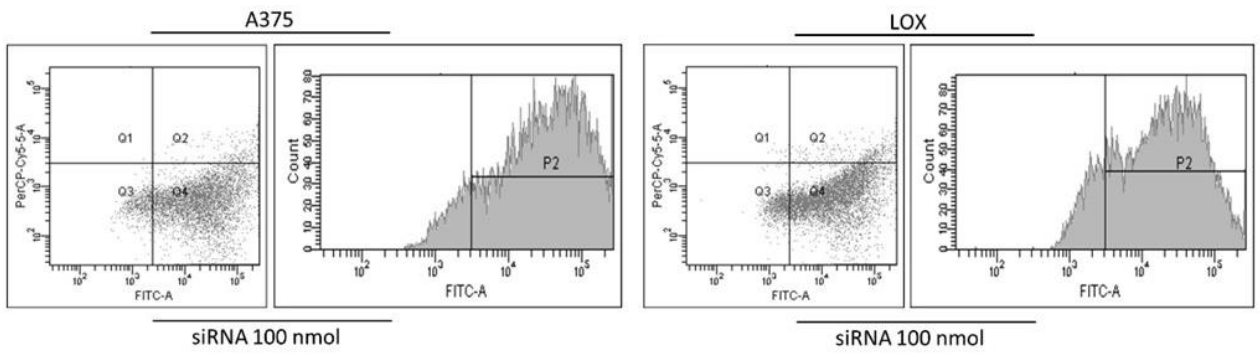

B

A375

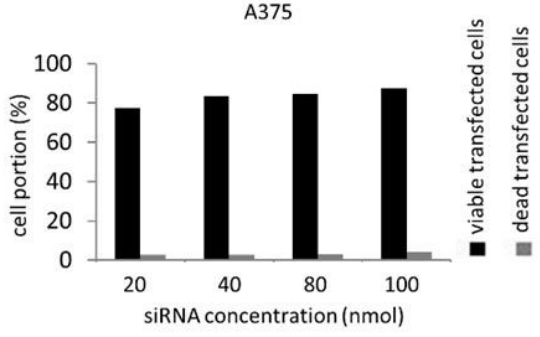

C

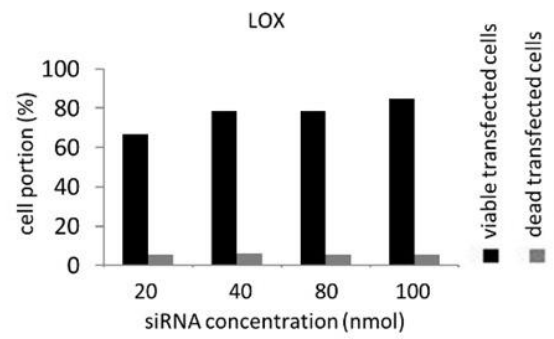

Figure 7: Efficient siRNA transfection by high siRNA concentration.

(A) Histogram of FACS transfection analysis of melanoma cell lines A375 and LOX treated with FITC labelled control siRNA. Signals in section Q4 represent viable transfected cells, whereas section Q2 represents dead transfected cells. (B) FACS transfection analysis of A375 cells and (C) LOX cells treated with different concentrations of FITC labelled control siRNA $72 \mathrm{~h}$ after transfection. Cells treated with a concentration of $100 \mathrm{nmol}$ showed the highest portion of viable transfected cells, while the portion of unviable transfected slightly increased. The mean of two independent experiments is shown. Error bars are \pm SD.

Taken together, results of FACS analysis and western blotting, efficient siRNA transfection and c-Rel down-regulation along with highest viability was obtained by a siRNA concentration of $100 \mathrm{nmol}$. This siRNA concentration was therefore used on for further experiments investigating the function of c-Rel. 


\subsection{Functional impacts of c-Rel down-regulation on melanoma cells}

\subsection{1 c-Rel down-regulation and cell growth}

As previously shown, c-Rel activity and expression increases with melanoma growth and progression (McNulty et al. 2004). For this reason, cell growth was examined in melanoma cell lines A375 and LOX 72h after siRNA transfection and quantified by counting cells of at least 5 microscopic fields with a magnification of $100 x$. Compared to control, cell growth of c-Rel down-regulated cells was significantly reduced by about $30 \%(p<0.05)$ in both cell lines (Figure $8 A-B)$.

Additionally, cell viability was analyzed performing MTT cell viability assay. c-Rel down-regulated LOX cells showed a slightly reduced viability $(16 \%, p<0.05)$ and no changes in viability of $A 375$ cells in comparison to control cells were observed $72 \mathrm{~h}$ after transfection (Figure $8 \mathrm{C}$ ). Furthermore, cell proliferation was analyzed by BrdU incorporation analysis and was affected by c-Rel down-regulation, neither in A375 nor in LOX cells (Figure 8D). 
A

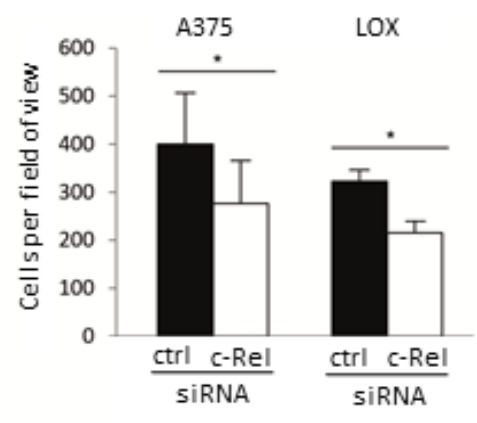

C

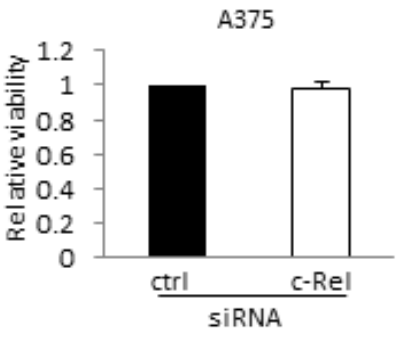

D

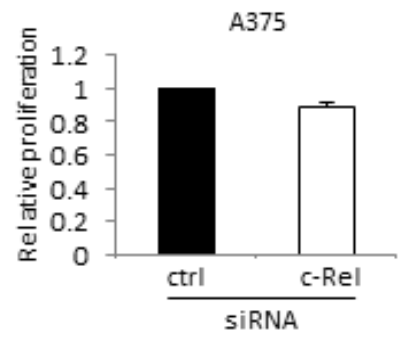

B
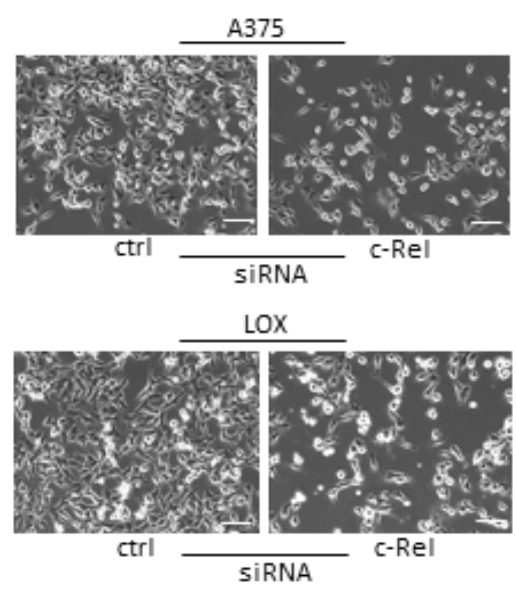

LOX

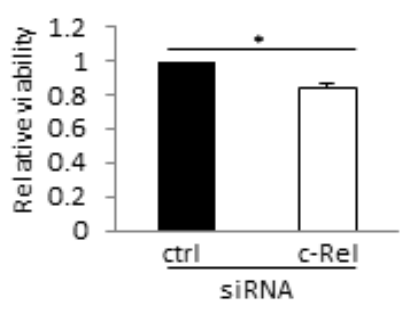

LOX

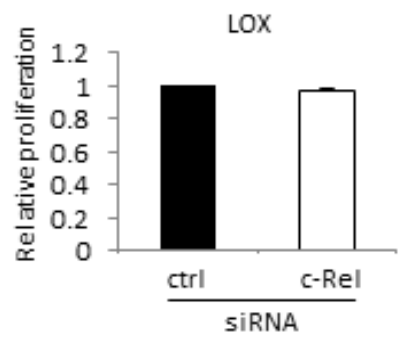

Figure 8: c-Rel down-regulation reduces cell growth.

(A) Quantification of cell growth $72 \mathrm{~h}$ after transfection. The number of c-Rel siRNA transfected cells (c-Rel) counted in at least six microscopic fields is clearly reduced compared to control siRNA transfected cells (ctrl). The mean of three independent experiments is shown. (B) Phase contrast images (100x) of control siRNA and c-Rel siRNA treated A375 and LOX cells. Bar=10 $\mu$ m (C) MTT cell viability assay of cell lines A375 and LOX $72 \mathrm{~h}$ after transfection. c-Rel siRNA treated LOX cells showed a slightly reduced cell viability unlike $A 375$ cells. The mean of the relative absorbance of three independent experiments is shown. (D) BrdU proliferation assay of cell lines A375 and LOX showed no difference in cell proliferation $72 \mathrm{~h}$ after transfection. The mean of the relative absorbance of 2 independent experiments is shown. Error bars are $\pm \mathrm{SEM},{ }^{*}$ indicates $p \leq 0.05$. 


\subsection{2 c-Rel down-regulation and apoptosis}

Apoptosis of A375 and LOX cells was investigated utilizing a cell death detection assay based on the detection of apoptotic vesicles containing nucleosomes and histones (Roche, Cell Death Detection ELISA ${ }^{\text {PLUS }}$ ). Strikingly, the relative number of apoptotic LOX cells was highly increased by about $170 \%$ after c-Rel siRNA transfection compared to control siRNA $(p<0.01)$, whereas the number of apoptotic $A 375$ cells remained unchanged $(p=0,57)$ (Figure 9A). Due to the high increase of apoptosis rate in LOX cells, the expression of the three anti-apoptotic markers Mcl1, Bcl-xl and Bcl-2 was analyzed by western blotting. However, the expression of these anti-apoptotic markers was not altered after c-Rel downregulation compared to control (Figure 9B). 
A

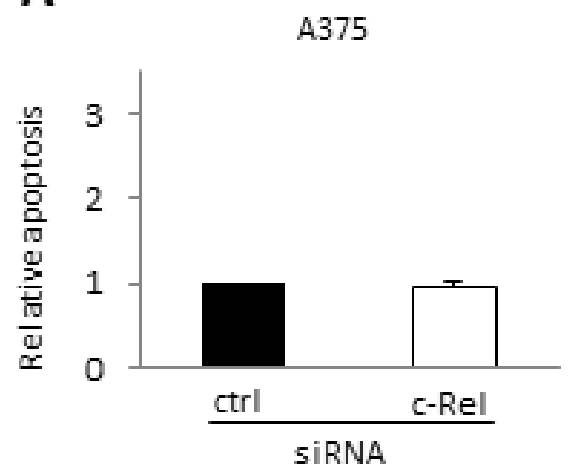

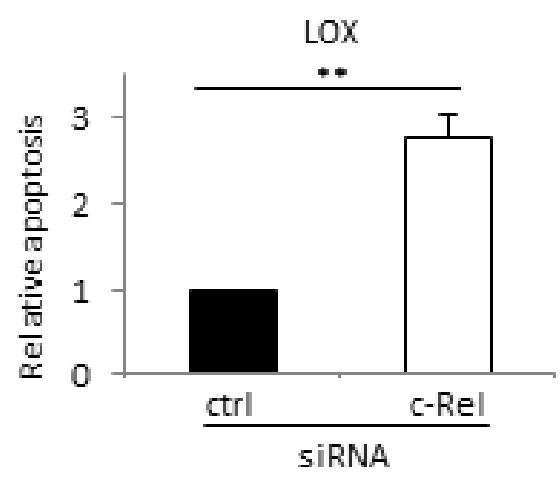

B

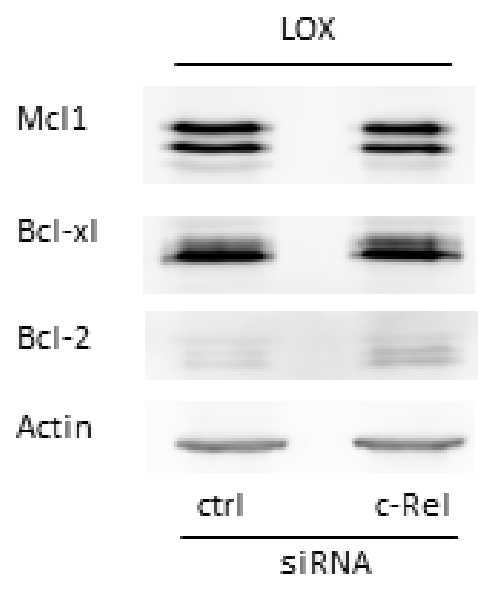

Figure 9: Apoptosis rate in LOX cells is increased by c-Rel down-regulation.

(A) Apoptosis assay $72 \mathrm{~h}$ after siRNA transfection. The apoptosis rate in c-Rel siRNA transfected LOX cells (c-Rel) is highly increased compared to control (ctrl). The mean of three independent experiments is shown. (B) Western blotting of $40 \mu \mathrm{g}$ whole cell lysate of control siRNA and c-Rel siRNA transfected cells $72 \mathrm{~h}$ after transfection. LOX cells show no change of the three antiapoptotic markers $\mathrm{Mcl} 1, \mathrm{Bcl}-\mathrm{xl}$ and $\mathrm{Bcl}-2$ in c-Rel siRNA transfected cells. Actin was used as loading control. One of three representative experiments is shown. Error bars are $\pm \mathrm{SEM} ;{ }^{* *}$ indicates $p \leq$ $0.01, * p \leq 0.05$. 


\subsection{3 c-Rel down-regulation affects cell cycle phase distribution and mitosis}

To further characterize the observed growth reduction of melanoma cells after c-Rel down-regulation, cell cycle phase distribution and the mitotic cell portion were examined by FACS analysis using propidium-iodide. Exemplary histograms of cell cycle phase distribution in LOX cells are shown depicting the respective cell cycle phases (Figure 10A).

Regarding cell cycle phase distribution, A375 cells showed a reduced portion of cells in $\mathrm{G} 1 / \mathrm{G} 0$ phase ( $55 \%$ vs $50 \%$; $p<0.05$ ), an increased number of cells in $\mathrm{G} 2 / \mathrm{M}$ phase $(22 \%$ vs $23 \% ; p<0.05)$ and a twofold increase of polyploid cells $(1,4 \%$ vs $3 \% ; p<0.05$ ) following $c-R e l$ down-regulation (Figure 10B).

In LOX cells, c-Rel down-regulated cells showed a tendency of reduced cell portion in $\mathrm{GO} / \mathrm{G} 1$ phase ( $50 \%$ vs $44 \%$; $p<0.05$ ), while cell portion of $\mathrm{G} 2 / \mathrm{M}$ phase was significantly increased ( $24 \%$ vs $29 \%$; $p<0.05$ ) and cell portion of polyploid cells $(1,8 \%$ vs $2,7 \% ; p<0.05)$ (Figure $10 \mathrm{C})$.

In addition, the portion of mitotic cells was determined using phospho-MPM2 antibody for FACS analysis, which binds to phospho amino acid-containing epitopes, expressed on over 50 proteins of M phase eukaryotic cells. After c-Rel down-regulation, LOX cells showed a significant increase of mitotic cells $(1,6 \%$ vs $4,3 \% ; p<0.05)$ whereas in $A 375$ cells, the mitotic cell portion remained unchanged compared to control (2,2\% vs $2,1 \% ; p>0.05)$ (Figure 10D-E).

Additionally, expression of another mitotic marker, phospho-histone H3 ( $p$ $\left.\mathrm{H} 3^{\mathrm{Ser} 10}\right)$, was examined by western blotting. Whereas LOX cells showed an increase of $\mathrm{p}-\mathrm{H} 3^{\mathrm{Ser} 10}$ of about $80 \%$ as revealed by densitometric analysis (Figure 10G) A375 cells showed no increased expression after c-Rel down-regulation (Figure 10F).

In summary, c-Rel down-regulation shifts the cell cycle phase distribution towards G2/M and polyploid phase in both A375 and LOX cells and strongly increases the mitotic portion determined by $\mathrm{p}-\mathrm{MPM} 2$ and $\mathrm{p}-\mathrm{H} 3$ staining in LOX cells but not in A375 cells. 
A

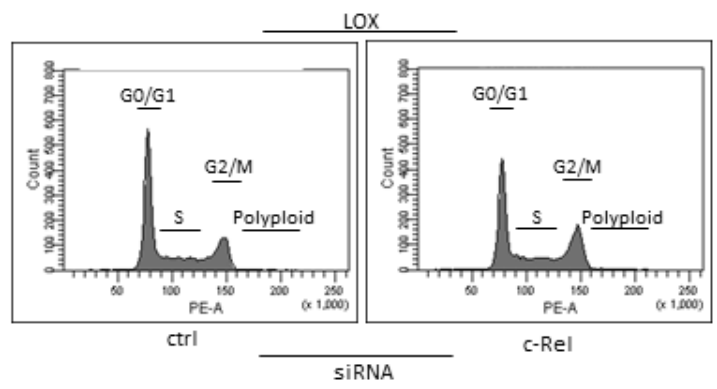

B

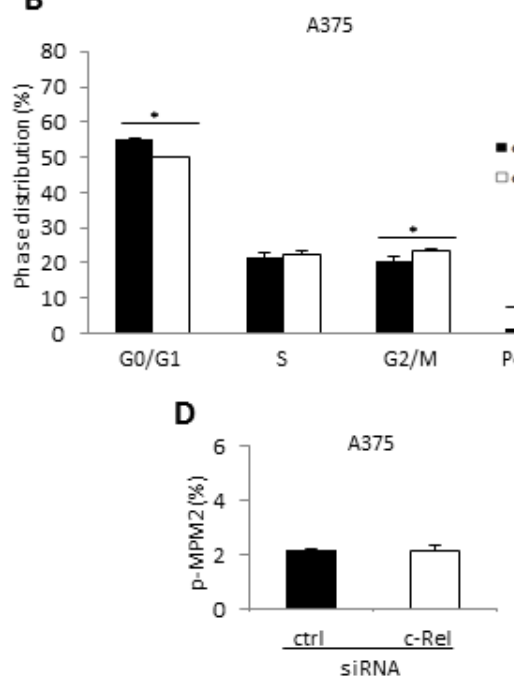

$\mathbf{F}$

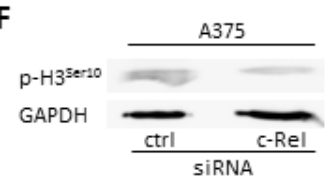

C
LOX

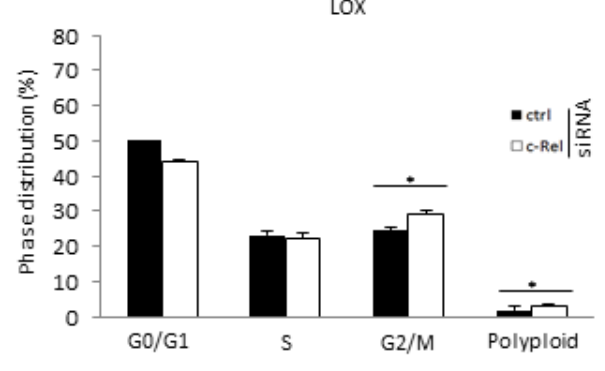

E

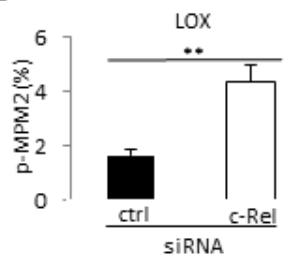

G

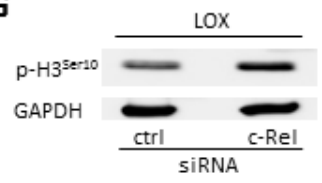

Figure 10: c-Rel down-regulation changes cell cycle phase distribution.

(A) Histogram of FACS cell cycle analysis of control siRNA (ctrl) and c-Rel siRNA transfected cells (cRel) stained with propidium-iodide $72 \mathrm{~h}$ after transfection. (B) FACS cell cycle analysis of c-Rel down-regulated $A 375$ cells revealed changes in the distribution of cell cycle phases G1/G0, G2/M and the number of polyploid cells compared to control $72 \mathrm{~h}$ after transfection. The mean of 4 independent experiments is shown. (C) FACS analysis of c-Rel down-regulated LOX cells revealed changes in the distribution of cell cycle phases G2/M and the number of polyploid cells compared to control $72 \mathrm{~h}$ after transfection. The average of 4 experiments is shown. (D) FACS analysis of A375 cells labelled with mitosis antibody MPM2 showed no change in the amount of mitotic cells $72 \mathrm{~h}$ after transfection, whereas LOX cells (E) showed an increase of mitotic cells. The average of four experiments is shown. (F) Western blotting of $50 \mu \mathrm{g}$ whole cell lysate of control siRNA and c-Rel siRNA transfected cells $72 \mathrm{~h}$ after transfection. Cell line A375 shows no change of the mitotic marker $\mathrm{p}-\mathrm{H} 3^{\mathrm{Ser} 10}$ in c-Rel down-regulated cells, however LOX cells (G) showed a strong increase of $\mathrm{p}-\mathrm{H} 3^{\mathrm{Ser} 10}$. GAPDH was used as loading control. One of three representative experiments is shown. Error bars are $\pm \mathrm{SEM}, * * p \leq 0.01, * p \leq 0.05$. 
To elucidate mechanisms of the observed changes on cell cycle phase distribution after c-Rel down-regulation, morphology of mitotic spindles was further investigated. For visualization of mitotic spindles, centrosomes were imaged by immunostaining of pericentrin, which is an integral component of the centrosome, and the microtubule cytoskeleton by $\beta$-tubulin staining (Delaval and Doxsey 2010). Control cells of A375 and LOX showed predominantly normal mitotic cells as depicted in Figure $11 \mathrm{~A}$ and $\mathrm{C}$ in the first column. Mitotic A375 and LOX control cells in metaphase are depicted with an oblong chromatin and a symmetrical mitotic spindle apparatus with two opposite poles organized by centrosomes. In the bottom row of LOX control cells, mitosis in late metaphase is depicted. In contrast to this normal mitotic spindle formation, c-Rel downregulated cell lines A375 and LOX showed centrally located and fragmented centrosomes and a disorganized microtubule cytoskeleton, which are indicated by arrows in Figure $11 \mathrm{~A}$ and C. Bipolar aberrant A375 and LOX cells showed centrosomes, that formed two poles with a connecting but also disorganized microtubule cytoskeleton, as indicated by arrowheads (Figure 11A,C). Additionally, in multipolar aberrant cells of cell lines A375 and LOX, several centrosomes and three or more spindle poles were found (data not shown). 
Quantitative evaluation of at least 100 mitotic cells per sample showed a tendency towards more aberrant mitotic spindle morphologies in A375 cells after c-Rel down-regulation (27,9\% vs 38,6\%; p>0.05) (Figure 11B). In contrast, quantitative evaluation of spindle morphologies in LOX cells resulted in a significantly increased number of cells with aberrant mitotic spindles $(20,6 \%$ vs $48,7 \% ; p<0,05$ ) (Figure 11C-D). Subclassification of aberrant mitotic spindles showed a significant increase of monopolar mitotic spindles $(11,9 \%$ vs $52 \%$; $p<0,01)$. Moreover, a significantly reduced portion of bipolar mitotic spindles was observed in c-Rel down-regulated cells $(71,7 \%$ vs $42,2 \%$; $p<0,05)$ (Figure $11 E)$.

In conclusion, while mitotic spindles in A375 cells are only slightly influenced by c-Rel down-regulation, aberrant spindle formation is highly increased in LOX cells. 
A

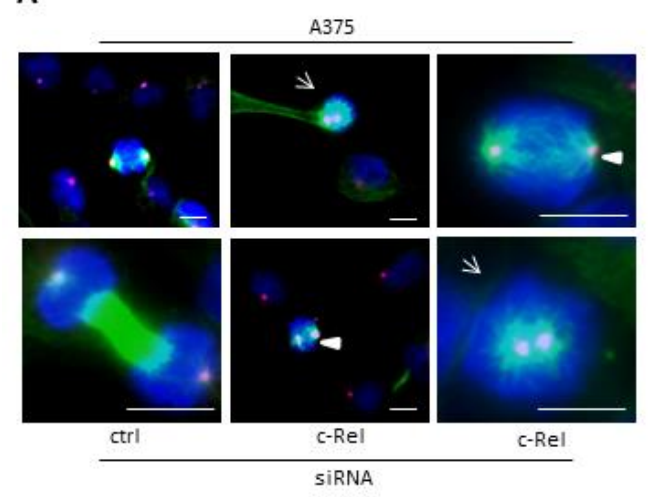

C

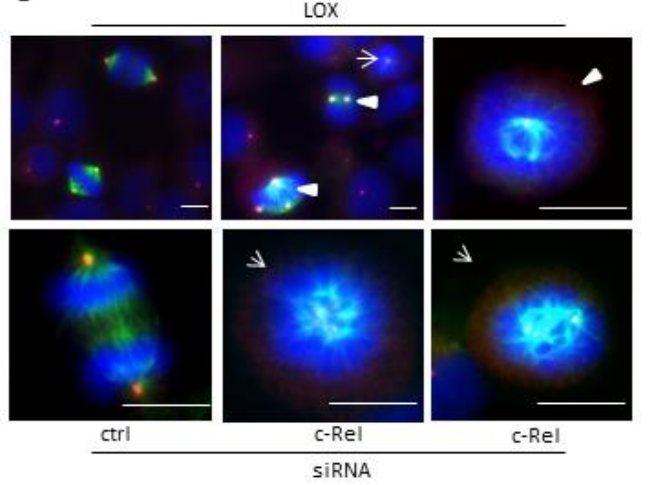

B

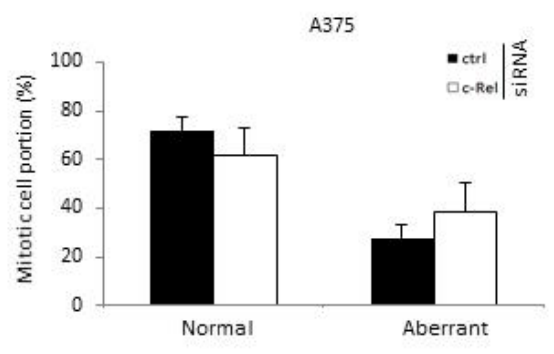

D

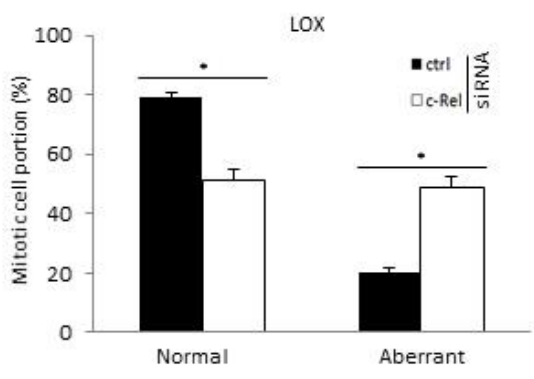

E LOX

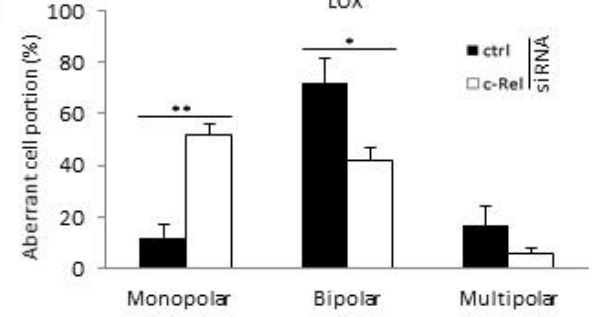

Figure 11: c-Rel down-regulation leads to an increase of aberrant mitotic cells in cell line LOX.

(A) Photographs of control siRNA and c-Rel siRNA (200x, 1000x) treated A375 cells stained for $\beta$ tubulin and pericentrin $72 \mathrm{~h}$ after transfection. Aberrant cells with monopolar mitotic spindles are indicated by arrows and bipolar mitotic spindles by arrowheads. Images were digitally enhanced. Bar $=10 \mu \mathrm{m}$. (B) Quantitative evaluation of mitotic cell portion of control and c-Rel siRNA transfected A375 cells indicates a tendency towards an increased number of mitotic cells with aberrant spindle morphology $72 \mathrm{~h}$ after c-Rel knockdown. The mean of 3 experiments is shown. Error bars are \pm SEM. $*_{*}^{*}$ indicates $p \leq 0.01, * p \leq 0.05$ (C) Pictures of LOX cells treated with control siRNA and c-Rel siRNA (200x, 1000x), which were stained with $\beta$-Tubulin and pericentrin $72 \mathrm{~h}$ after transfection. Aberrant cells with monopolar mitotic spindles are indicated by arrows and bipolar mitotic spindles by arrowheads. Images were dgitally enhanced. Bar $=10 \mu \mathrm{m}$. (D) Fluorescene microscopy analysis of cells reveals a larger number of mitotic cells with aberrant spindle morphology $72 \mathrm{~h}$ after c-Rel knockdown. The mean of 3 experiments is shown. (E) Quantitative evaluation of aberrant mitotic control and c-Rel siRNA LOX cells reveals a larger portion of aberrant mitotic cells with monopolar spindles. The mean of three experiments is shown. Error bars are $\pm \mathrm{SEM}$; ** indicates $p \leq 0.01,{ }^{*} p \leq$ 0.05 . 


\section{Discussion}

Malignant melanoma is unique in its very aggressive growth pattern and progression compared to other types of skin cancer (Satyamoorthy and Herlyn 2002). In case of metastasising disease, less than $10 \%$ of the patients survive the following five years despite therapy (Balch et al. 2009).

The chemotherapeutical options are limited because melanoma cells have been widely resistant to the previous systemic therapy. Several factors are involved in the chemoresistant growth pattern of melanoma cells and have only been partially elucidated yet. In the last several years, approval of promising new chemotherapeutic agents such as vemurafenib (B-RAF inhibitor) and ipilimumab (CTLA-4 inhibitor), has improved the prognosis for patients in view of overall survival (Eggermont and Robert 2011). Nonetheless, the benefit for overall survival are often limited and the new therapies are not suitable for each patient (Nazarian et al. 2010). Therefore, it is important to further clarify the mechanisms of chemoresistance and to find new potential targets for treatment.

In terms of identifying other new therapeutical targets for melanoma treatment, the transcription factor NF-KB has been of special interest (Bharti and Aggarwal 2002). Along with other dysregulated key signaling pathways like the MAPKpathway or the PI3K/AKT-pathway, the NF-KB pathway is also involved in melanoma development and progression (Amiri and Richmond 2005). For example, pre-clinical approaches showed an increased tumor susceptibility to chemotherapy in vivo when treating melanoma cell injected mice with the IKK $\beta$ inhibitor KINK-1 and doxorubicin or camptothecin (Schon et al. 2008).

The NF-KB subunit c-Rel functions as an oncogene in many solid tumors (Hunter et al. 2016). In terms of malignant melanoma, an immunohistochemical analysis of human tissue biopsies showed elevated c-Rel expression in melanoma cells compared to melanocytes derived from normal skin and nevus, suggesting involvement of c-Rel in melanoma development and progression (McNulty et al. 2004). 
Thus, the aim of this study was to investigate the functional role of c-Rel in human melanoma cell lines concerning tumor development and progression.

\subsection{Variable c-Rel expression in different melanoma cell lines}

In this study, seven human melanoma cell lines (A375, LOX, Mel2a, MeWo, MV3, MMNH, Sk-Mel-23) derived from primary tumor and metastasis were characterized regarding c-Rel mRNA and protein expression level.

While c-Rel mRNA expression level was quite similar in all cell lines, a higher cRel protein expression level was detected in cell lines A375, derived from a primary tumor (Giard et al. 1973), and LOX, derived from a metastasis (Fodstad et al. 1988; Fodstad et al. 1984) in comparison to the other cell lines. This may suggest that the level of c-Rel protein expression does not depend on the metastatic status of melanoma cells. Previously, it was demonstrated that there is a constitutive activation of the NF-KB pathway in melanoma cells, but at different levels (Shattuck-Brandt and Richmond, 1997). In this context, it has also been shown that cell lines MMNH and MV3 have a higher endogenous NFKB activity compared to A375 and LOX. However, there is only a slight correlation between NF-KB activity and expression levels of the subunits (Amschler et al. 2010; Pletz et al. 2012).

In context of underlying mutations modulating NF-KB activation, it was shown that the PTEN-encoding gene, exerting tumor suppressing functions, is not mutated neither in A375 nor in LOX cells (Schneider et al. 2014). In this context, it was also demonstrated that antagonizing the PI3K/AKT signaling pathway decreases NF-KB activation (Gupta et al. 2010).

It is known that BRAF or N-Ras mutations are often associated with NF-KB activation in melanoma cells, though the exact mechanism is still unclear (Ueda and Richmond 2006). These mutations were identified as activators of the MAPK pathway, which in turn activates secretion of TNF $\alpha$ and chemokines. Again, these are activators of NF-KB, which implicates an indirect activation of NF- $\mathrm{KB}$ by BRAF or N-Ras mutations (Gaggioli et al. 2005; Siwak et al. 2005). Interestingly, BRAF ${ }^{V 600 E}$ mutation was detected in cell line $A 375$ in concert with a constitutively activated MAPK pathway (Sumimoto et al. 2006; Sutton et al. 2016). Additionally, cell line LOX also harbors $B R A F^{V 600 E}$ mutation without any concurrent mutations in PI3K/AKT (B Chen et al. 2012). In this context, NF-KB 
activity in melanoma cell lines A375 and LOX may be partially affected by an underlying $B R A F^{V 600 E}$ mutation by indirect mechanisms (PI3K/AKT-signaling pathway, MAPK-pathway).

\section{2 c-Rel exerts various functions in human melanoma cells in vitro}

In functional investigations of the human melanoma cell lines A375 and LOX, it could be shown that cell growth was decreased in vitro after c-Rel downregulation. Further experiments showed a slight reduction of viability but no decrease in proliferation of LOX cells, while A375 cells showed neither a change in viability nor in proliferation after c-Rel down-regulation. This is in contrast to studies in keratinocytes, in which c-Rel suppression impaired viability and proliferation (Lorenz et al. 2014).

Furthermore, no changes regarding apoptosis in A375 cells following c-Rel downregulation but a strong apoptotic increase of LOX cells could be shown. However, expression of apoptotic markers $\mathrm{Mcl} 1, \mathrm{Bcl}-\mathrm{xl}$ and $\mathrm{Bcl}-2$ was unaltered in $\mathrm{c}-\mathrm{Rel}$ down-regulated LOX cells. Supportively, additional experiments using a second c-Rel siRNA construct did not induce apoptosis after c-Rel down-regulation in LOX cells suggesting no influence of c-Rel in apoptosis in the studied melanoma cell lines (unpublished data V. Lorenz).

It is known that c-Rel is the only subunit of NF-KB exerting direct oncogenic properties. It was shown that v-Rel (the avian mutated homologue of c-Rel) leads to a malignant transformation of chicken hematopoietic cells in vitro (IS Chen et al. 1981). Additionally, increased nuclear activation of c-Rel was demonstrated in various forms of cancer (Rodig et al. 2005). In support of this theory, an overexpression of subunit c-Rel induced a transformation in primary avian fibroblasts (Abbadie et al. 1993). Furthermore, c-Rel silencing in B cell tumor cells led to apoptosis of tumor cells and growth arrest (Tian and Liou 2009). Again, reduced proliferation of B-cells was demonstrated in c-rel- mice (Liou and Hsia 2003). Accordingly, an anti-apoptotic function of c-Rel has been shown recently for human keratinocytes in vitro (Lorenz et al. 2014).

Melanoma cells show an extraordinarily chemoresistant growth pattern, partly due to complex alterations of factors regulating extrinsic and intrinsic apoptosis. The latter, the mitochondrial Apaf/Casp9-pathway is often altered in melanoma 
cells. Besides the transcription factor NF-kB, cytokines such as TNF $\alpha$, TRAIL and FasL also activate extrinsic apoptosis (Soengas and Lowe 2003).

In summary, given that there is a complex system of anti-apoptotic alterations in intrinsic and extrinsic apoptosis in melanoma cells, it may be assumed that cRel has none or at least a limited effect on apoptosis in melanoma cell lines A375 and LOX, which could be compensated by the network of other anti-apoptotic alterations. However, the study identified underlying processes concerning cell cycle and mitosis.

\section{3 c-Rel modifies cell cycle phase distribution and mitotic spindle formation}

In melanoma cells, cell proliferation is often increased because of activating mutations with in the BRAF, NRAS, PTEN, NF1, C-KIT and CDKN2A-encoding genes (Fedorenko et al. 2015). Loss of CDK4 inhibitors p16 ${ }^{\text {INK4a }}$ and p14 $4^{\text {ARF }}$ encoded by CDKN2A influences the cell cycle via p53 and RB respectively, resulting in increased cell proliferation. Therefore, patients with mutated CDKN2A locus could benefit from CDK4/6 inhibitors in melanoma therapy (Piepkorn 2000; Regad 2013).

Because the transcription factor NF-KB is known to be involved in cell cycle regulation and elevated expression of c-Rel in melanoma cells has been previously shown, c-Rel was further analyzed in this study (Guttridge et al. 1999; McNulty et al. 2004).

This study demonstrated a significant increase of A375 and LOX cells in G2/Mphase after c-Rel down-regulation. Also, A375 cells and LOX cells showed a highly increased portion of polyploid cells. Further examination of mitotic cells revealed a strong increase of mitotic LOX cells and of the corresponding mitotic marker $\mathrm{p}-\mathrm{H} 3^{\mathrm{Ser} 10}$ after c-Rel down-regulation, whereas $\mathrm{A} 375$ cells did not show an increase of mitotic cell portion and of the mitotic marker $\mathrm{p}-\mathrm{H} 3^{\text {Ser10. }}$.

Beforehand, cell cycle regulatory functions of c-Rel have already been demonstrated in various benign and malignant cell types. Regarding $\mathrm{G} 1 / \mathrm{S}$ phase, an effect of c-Rel was shown in HeLa cells (Bash et al. 1997). Furthermore, G1phase arrest of B-cells was identified in c-rel ${ }^{-/-}$mice (Grumont et al. 1998). 
Studies in the same animal model examining liver injury and regeneration described a reduced hepatocyte proliferation, based on c-Rel promoter interaction with the mitotic regulator FOXM1 and the consecutive downstream of cyclin B1 and Cdc25, suggesting a function in later stages of the cell cycle (Gieling et al. 2010).

Regarding keratinocytes, c-Rel deficient triple knock-out mice (rela ${ }^{-/}$, c-rel ${ }^{-1}$, tnfa ${ }^{-1-}$ ) showed a thinned epidermis due to a cell cycle block in G1-phase (Gugasyan et al. 2004). Moreover, c-Rel down-regulation in HaCaT keratinocytes led to a G2/M cell cycle delay with aberrant mitotic spindle formations (Lorenz et al. 2014).

Similar features concerning G2/M-phase were elucidated in malignant melanoma cells in this study, also suggesting a relation between c-Rel and cell cycle regulation in A375 and LOX cells. However, the exact mechanisms of c-Rel influencing the cell cycle of melanoma cells have to be clarified in further experiments, especially alterations of cyclins and cyclin dependent kinases and other key cell cycle regulatory molecules need to be studied.

Moreover, it is important to further clarify differing functions of c-Rel in cells derived from primary tumor (A375) and cells derived from metastasis (LOX). Results of this study indicate similar cell cycle alterations in both cell lines, whereas mitotic cell portion was only elevated in LOX cells, detected by using the mitotic marker $\mathrm{p}-\mathrm{H} 3^{\mathrm{Ser} 10}$ and MPM-2 (Hale et al. 2013).

Hence, the observed increase of cells in G2/M-phase of cell line A375 may reflect rather cells in G2-phase, while LOX cells actually show an increase of mitotic cells.

Possibly, c-Rel down-regulation impairs cell cycle regulation differently in metastatic melanoma cells (LOX) compared to primary tumor cells. However, this needs to be clarified in further experiments.

Further analysis after c-Rel down-regulation of mitotic cells showed a high percentage of cells with aberrant mitotic structures significantly increased for LOX cells with a particular increase in monopolar mitotic spindles. In contrast, A375 cells did not show an alteration in mitotic structures after c-Rel downregulation. 
Polyploid cells may occur due to unsolved problems during mitosis. Normally, this is prevented by a central mitotic regulatory checkpoint, which is called the SAC (Rieder and Maiato 2004). The SAC is activated by improperly attached kinetochores, detected by proteins belonging to the MCC (Musacchio and Salmon 2007). After lingering in mitotic arrest in early mitotic stages for hours, cells either undergo apoptosis or exit mitosis by mitotic slippage into G1-phase, resulting in a tetraploid respectively polyploid cell status. As a consequence, either apoptosis is induced because of their tetraploid state or cells may enter another round of cell cycle (Huang et al. 2009).

With respect to the increased portion of polyploid cells in both melanoma cell lines, impaired mitotic spindle formations were only observed in LOX cells after c-Rel down-regulation, assuming possible difficulties during early mitotic progression. Nevertheless, the exact mechanisms, which lead to these spindle abberations need to be elucidated in further studies. Intriguingly, further experiments including c-Rel down-regulation in cell lines MV3 and Sk-Mel-23, both derived from metastasis, also revealed similar spindle alterations (unpublished data V. Lorenz).

Interestingly, Cui et al. showed that overexpression of the proto-oncogenic BRaf leads to multipolar mitotic spindle formations, supernumerary centrosomes and consecutively aneuploidy and CIN in melanocytes (Cui et al. 2010). Future studies with special focus on c-Rel signaling may further elucidate this connection.

Since about $70 \%$ of cancer cells of various tissue types show an increased rate of chromosome mis-segregations and aneuploidy, CIN represents a form of genomic instability, which is characteristic for cancer (Cimini 2008; Weaver and Cleveland 2006). For example, a higher genomic variability was detected in metastatic melanoma cells compared to non-metastatic primary tumor cells, implicating a role for CIN in melanoma progression (Dabas et al. 2012). Accordingly, another study analyzed CIN in different melanoma cell lines and revealed a relatively low CIN rate for $\mathrm{A} 375$ cells, derived from primary tumor (Kaufmann et al. 2014). However in this study, LOX cells were not classified. Further studies to determine the CIN rate of LOX cells may therefore be interesting to support this hypothesis. 
In this study, A375 cells showed no alterations in spindle morphology, while LOX cells showed a highly increased rate of spindle abnormalities. Therefore, LOX cells seem to be more susceptible to develop aberrant mitotic spindle formations after c-Rel down-regulation than A375 cells.

In view of the cell cycle regulatory influence of c-Rel, inhibition of c-Rel may serve as a therapeutic approach. Therapeutic potential of c-Rel has already been shown in B-cell tumors, in which c-Rel silencing induced apoptosis of tumor cells and growth arrest in vitro and in vivo (Tian and Liou 2009). In this context it may be of interest that a small-molecule inhibitor of c-Rel IT-603 led to a reduced cRel-induced activation of $\mathrm{T}$ cells in mice, thereby presenting a promising potential therapy of graft versus host disease (Shono et al. 2016). Moreover, Ramos et al. demonstrated in patients, suffering from adult T-cell leukemia/lymphoma (ATLL), that increased c-Rel expression was associated with resistance to treatment with zidovudine and interferon alpha. Selective inhibition of c-Rel function may help to optimize treatment response in this setting (Ramos et al. 2007). Similarily, c-Rel inhibition may be an interesting future target in melanoma treatment. This study suggests an impact of c-Rel on cell cycle regulation and possibly mitotic spindle formations in primary and metastatic melanoma cells. 


\section{Summary and conclusion}

The transcription factor NF-KB, which is one of the central regulators regarding cell growth, proliferation, apoptosis, inflammation and invasion, was shown to also play a role in melanoma development and progression. This thesis aimed to further enlighten the role of the NF-KB subunit c-Rel in malignant melanoma. For this purpose, seven melanoma cell lines derived from primary tumor and metastasis were characterized regarding c-Rel expression and growth pattern, revealing varying c-Rel expression levels and growth features. Transient downregulation of c-Rel by siRNA in melanoma cell lines A375 (derived from primary tumor) and LOX (derived from metastasis) led to growth inhibition, suggesting a pro-proliferative function. Altered cell cycle distribution, namely increased portions of cells in G2/M phase and increased numbers of polyploid cells were detected after c-Rel down-regulation in both cell lines. Additionally, c-Rel downregulation leads to an altered mitotic spindle morphology in LOX cells with predominantly monopolar spindle formations. Altogether, these results propose an involvement of c-Rel in cell cycle regulation, thereby suggesting a novel tumor-promoting role in human melanoma cells with putative implications as a new combination target in melanoma therapy. 


\section{Literature}

Abbadie C, Kabrun N, Bouali F, Smardova J, Stehelin D, Vandenbunder B, Enrietto PJ (1993): High levels of c-rel expression are associated with programmed cell death in the developing avian embryo and in bone marrow cells in vitro. Cell $\underline{75}, 899-912$

Abildgaard C, Guldberg P (2015): Molecular drivers of cellular metabolic reprogramming in melanoma. Trends Mol Med 21, 164-171

Adhikari A, Xu M, Chen ZJ (2007): Ubiquitin-mediated activation of TAK1 and IKK. Oncogene 26, 3214-3226

Alberts B, Johnson A, Lewis J, Raff M, Roberts K, Walter P: Molecular Biology of the Cell. Fourth edition; Garland Science, New York 2002. http://www.ncbi.nlm.nih.gov/books/NBK26869/; (Zugriff am 06.03.2016)

Amiri KI, Richmond A (2005): Role of nuclear factor-kappa B in melanoma. Cancer Metastasis Rev 24, 301-313

Amschler K, Schon MP, Pletz N, Wallbrecht K, Erpenbeck L, Schon M (2010): NF-kappaB inhibition through proteasome inhibition or IKKbeta blockade increases the susceptibility of melanoma cells to cytostatic treatment through distinct pathways. J Invest Dermatol 130, 1073-1086

Azzola MF, Shaw HM, Thompson JF, Soong SJ, Scolyer RA, Watson GF, Colman MH, Zhang $Y$ (2003): Tumor mitotic rate is a more powerful prognostic indicator than ulceration in patients with primary cutaneous melanoma: an analysis of 3661 patients from a single center. Cancer $\underline{97}$, 1488-1498

Balch CM, Gershenwald JE, Soong SJ, Thompson JF, Atkins MB, Byrd DR, Buzaid AC, Cochran AJ, Coit DG, Ding S, et al. (2009): Final version of 2009 AJCC melanoma staging and classification. J Clin Oncol 27, 6199-6206

Bash J, Zong WX, Gelinas C (1997): c-Rel arrests the proliferation of HeLa cells and affects critical regulators of the $\mathrm{G} 1 / \mathrm{S}$-phase transition. Mol Cell Biol 17, 6526-6536

Bharti AC, Aggarwal BB (2002): Nuclear factor-kappa B and cancer: its role in prevention and therapy. Biochem Pharmacol $\underline{64}, 883-888$ 
Brenner M, Hearing VJ (2008): The protective role of melanin against UV damage in human skin. Photochem Photobiol 84, 539-549

Bruggen J, Fogh J, Sorg C (1981): Tumor production in the nude mouse, fibrinolytic activity and cross-reactivity with antimelanoma sera of various human tumor cell lines. J Cancer Res Clin Oncol 102, 141-152

Bucheit AD, Davies MA (2014): Emerging insights into resistance to BRAF inhibitors in melanoma. Biochem Pharmacol 87, 381-389

Cancer Genome Atlas (2015): Genomic Classification of Cutaneous Melanoma. Cell 161, 1681-1696

Chen B, Tardell C, Higgins B, Packman K, Boylan JF, Niu H (2012): BRAFV600E negatively regulates the AKT pathway in melanoma cell lines. PLoS One $\underline{7}$, e42598

Chen IS, Mak TW, O'Rear JJ, Temin HM (1981): Characterization of reticuloendotheliosis virus strain T DNA and isolation of a novel variant of reticuloendotheliosis virus strain $\mathrm{T}$ by molecular cloning. J Virol $\underline{40}, 800-$ 811

Cimini D (2008): Merotelic kinetochore orientation, aneuploidy, and cancer. Biochim Biophys Acta $\underline{1786}$, 32-40

Cui Y, Borysova MK, Johnson JO, Guadagno TM (2010): Oncogenic BRaf(V600E) induces spindle abnormalities, supernumerary centrosomes, and aneuploidy in human melanocytic cells. Cancer Res $\underline{70}$, 675-684

Curtin JA, Fridlyand J, Kageshita T, Patel HN, Busam KJ, Kutzner H, Cho KH, Aiba S, Brocker EB, LeBoit PE, et al. (2005): Distinct sets of genetic alterations in melanoma. N Engl J Med 353, 2135-2147

Dabas N, Byrnes DM, Rosa AM, Eller MS, Grichnik JM (2012): Diagnostic role of chromosomal instability in melanoma. J Skin Cancer 2012, 914267

Deep G, Agarwal R (2008): New combination therapies with cell-cycle agents. Curr Opin Investig Drugs $\underline{9}$, 591-604

Delaval B, Doxsey SJ (2010): Pericentrin in cellular function and disease. J Cell Biol 188, 181-190 
Diessenbacher $P$, Hupe $M$, Sprick MR, Kerstan A, Geserick $P$, Haas TL, Wachter T, Neumann M, Walczak H, Silke J, et al. (2008): NF-kappaB inhibition reveals differential mechanisms of TNF versus TRAIL-induced apoptosis upstream or at the level of caspase- 8 activation independent of cIAP2. J Invest Dermatol 128, 1134-1147

Duro E, Marston AL (2015): From equator to pole: splitting chromosomes in mitosis and meiosis. Genes Dev $\underline{29}, 109-122$

Egger ME, Dunki-Jacobs EM, Callender GG, Quillo AR, Scoggins CR, Martin RC, 2nd, Stromberg AJ, McMasters KM (2012): Outcomes and prognostic factors in nodular melanomas. Surgery 152, 652-659; discussion 659-660

Eggermont AM, Robert C (2011): New drugs in melanoma: it's a whole new world. Eur J Cancer 47, 2150-2157

Eggermont AM, Spatz A, Robert C (2014): Cutaneous melanoma. Lancet $\underline{383}, 816-827$

Fedorenko IV, Gibney GT, Sondak VK, Smalley KS (2015): Beyond BRAF: where next for melanoma therapy? Br J Cancer 112, 217-226

Flaherty KT, Infante JR, Daud A, Gonzalez R, Kefford RF, Sosman J, Hamid O, Schuchter L, Cebon J, Ibrahim N, et al. (2012): Combined BRAF and MEK inhibition in melanoma with BRAF V600 mutations. N Engl J Med 367, 1694-1703

Fodstad O, Hansen CT, Cannon GB, Statham CN, Lichtenstein GR, Boyd MR (1984): Lack of correlation between natural killer activity and tumor growth control in nude mice with different immune defects. Cancer Res 44, 4403-4408

Fodstad O, Aamdal S, McMenamin M, Nesland JM, Pihl A (1988): A new experimental metastasis model in athymic nude mice, the human malignant melanoma LOX. Int J Cancer $\underline{41}$, 442-449

Fullard N, Wilson CL, Oakley F (2012): Roles of c-Rel signalling in inflammation and disease. Int J Biochem Cell Biol $\underline{44}$, 851-860 
Fullard N, Moles A, O'Reilly S, van Laar JM, Faini D, Diboll J, Reynolds NJ, Mann DA, Reichelt J, Oakley F (2013): The c-Rel subunit of NF-kappaB regulates epidermal homeostasis and promotes skin fibrosis in mice. Am J Pathol $\underline{182}$, 2109-2120

Gaggioli C, Deckert M, Robert G, Abbe P, Batoz M, Ehrengruber MU, Ortonne JP, Ballotti R, Tartare-Deckert S (2005): HGF induces fibronectin matrix synthesis in melanoma cells through MAP kinase-dependent signaling pathway and induction of Egr-1. Oncogene 24, 1423-1433

Gandini S, Sera F, Cattaruzza MS, Pasquini P, Picconi O, Boyle P, Melchi CF (2005): Meta-analysis of risk factors for cutaneous melanoma: II. Sun exposure. Eur J Cancer 41, 45-60

Giard DJ, Aaronson SA, Todaro GJ, Arnstein P, Kersey JH, Dosik H, Parks WP (1973): In vitro cultivation of human tumors: establishment of cell lines derived from a series of solid tumors. J Natl Cancer Inst $\underline{51}$, 14171423

Gieling RG, Elsharkawy AM, Caamano JH, Cowie DE, Wright MC, Ebrahimkhani MR, Burt AD, Mann J, Raychaudhuri P, Liou HC, et al. (2010): The c-Rel subunit of nuclear factor-kappaB regulates murine liver inflammation, wound-healing, and hepatocyte proliferation. Hepatology 51, 922-931

Gilmore TD (2006): Introduction to NF-kappaB: players, pathways, perspectives. Oncogene $\underline{25}, 6680-6684$

Goydos JS, Shoen SL (2016): Acral Lentiginous Melanoma. Cancer Treat Res 167, 321-329

Greenwald HS, Friedman EB, Osman I (2012): Superficial spreading and nodular melanoma are distinct biological entities: a challenge to the linear progression model. Melanoma Res $\underline{22}, 1-8$

Grumont RJ, Rourke IJ, O'Reilly LA, Strasser A, Miyake K, Sha W, Gerondakis S (1998): B lymphocytes differentially use the Rel and nuclear factor kappaB1 (NF-kappaB1) transcription factors to regulate cell cycle progression and apoptosis in quiescent and mitogen-activated cells. J Exp Med 187, 663-674

Gugasyan R, Voss A, Varigos G, Thomas T, Grumont RJ, Kaur P, Grigoriadis $G$, Gerondakis S (2004): The transcription factors c-rel and RelA control 
epidermal development and homeostasis in embryonic and adult skin via distinct mechanisms. Mol Cell Biol 24, 5733-5745

Gupta SC, Sundaram C, Reuter S, Aggarwal BB (2010): Inhibiting NFkappaB activation by small molecules as a therapeutic strategy. Biochim Biophys Acta $\underline{1799}$, 775-787

Guttridge DC, Albanese C, Reuther JY, Pestell RG, Baldwin AS, Jr. (1999): NF-kappaB controls cell growth and differentiation through transcriptional regulation of cyclin D1. Mol Cell Biol 19, 5785-5799

Hale CS, Qian M, Ma MW, Scanlon P, Berman RS, Shapiro RL, Pavlick AC, Shao Y, Polsky D, Osman I, et al. (2013): Mitotic rate in melanoma: prognostic value of immunostaining and computer-assisted image analysis. Am J Surg Pathol 37, 882-889

Hayward NK (2003): Genetics of melanoma predisposition. Oncogene $\underline{22}$ 3053-3062

Heidorn SJ, Milagre C, Whittaker S, Nourry A, Niculescu-Duvas I, Dhomen N, Hussain J, Reis-Filho JS, Springer CJ, Pritchard C, et al. (2010): Kinasedead BRAF and oncogenic RAS cooperate to drive tumor progression through CRAF. Cell $\underline{140}$, 209-221

Hodis E, Watson IR, Kryukov GV, Arold ST, Imielinski M, Theurillat JP, Nickerson E, Auclair D, Li L, Place C, et al. (2012): A landscape of driver mutations in melanoma. Cell $\underline{150}, 251-263$

Houghton AN, Taormina MC, Ikeda $\mathrm{H}$, Watanabe $\mathrm{T}$, Oettgen HF, Old $\mathrm{U}$ (1980): Serological survey of normal humans for natural antibody to cell surface antigens of melanoma. Proc Natl Acad Sci U S A 77, 4260-4264

Huang HC, Shi J, Orth JD, Mitchison TJ (2009): Evidence that mitotic exit is a better cancer therapeutic target than spindle assembly. Cancer Cell 16, 347-358

Hunter JE, Leslie J, Perkins ND (2016): c-Rel and its many roles in cancer: an old story with new twists. Br J Cancer $\underline{114}$, 1-6

Johnson DB, Puzanov I (2015): Treatment of NRAS-mutant melanoma. Curr Treat Options Oncol 16, 15 
Kaufmann WK, Carson CC, Omolo B, Filgo AJ, Sambade MJ, Simpson DA, Shields JM, Ibrahim JG, Thomas NE (2014): Mechanisms of chromosomal instability in melanoma. Environ Mol Mutagen 55, 457-471

Kodera Y, Bean MA (1975): Antibody-dependent cell-mediated cytotoxicity for human monolayer target cells bearing blood group and transplantation antigens and for melanoma cells. Int J Cancer 16, 579-592

Koul D, Yao Y, Abbruzzese JL, Yung WK, Reddy SA (2001): Tumor suppressor MMAC/PTEN inhibits cytokine-induced NFkappaB activation without interfering with the IkappaB degradation pathway. J Biol Chem 276, 11402-11408

Kreiseder B, Holper-Schichl YM, Muellauer B, Jacobi N, Pretsch A, Schmid JA, de Martin R, Hundsberger H, Eger A, Wiesner C (2015): Alpha-catulin contributes to drug-resistance of melanoma by activating NF-kappaB and AP-1. PLoS One $\underline{10}$, e0119402

Kwong L, Chin L, Wagner SN (2007): Growth factors and oncogenes as targets in melanoma: lost in translation? Adv Dermatol 23, 99-129

Lara-Gonzalez P, Westhorpe FG, Taylor SS (2012): The spindle assembly checkpoint. Curr Biol 22, R966-980

Leitlinienprogramm-Melanom (2016): (Deutsche Krebsgesellschaft, Deutsche Krebshilfe, AWMF): Diagnostik, Therapie und Nachsorge des Melanoms, Kurzversion 2.0. AWMF Registernummer: 032/024OL, http://leitlinienprogramm-onkologie.de/Melanom.65.60.html, (Zugriff am: 26.05.2017)

Liou HC, Hsia CY (2003): Distinctions between c-Rel and other NF-kappaB proteins in immunity and disease. Bioessays $\underline{25}, 767-780$

Lo JA, Fisher DE (2014): The melanoma revolution: from UV carcinogenesis to a new era in therapeutics. Science $\underline{346}$, 945-949

Lorenz VN, Schon MP, Seitz CS (2014): c-Rel downregulation affects cell cycle progression of human keratinocytes. J Invest Dermatol 134, 415-422

Madhunapantula SV, Mosca PJ, Robertson GP (2011): The Akt signaling pathway: an emerging therapeutic target in malignant melanoma. Cancer Biol Ther 12, 1032-1049 
Madonna G, Ullman CD, Gentilcore G, Palmieri G, Ascierto PA (2012): NFkappaB as potential target in the treatment of melanoma. J Transl Med $\underline{10}, 53$

Maru GB, Gandhi K, Ramchandani A, Kumar G (2014): The role of inflammation in skin cancer. Adv Exp Med Biol 816, 437-469

McNulty SE, del Rosario R, Cen D, Meyskens FL, Jr., Yang S (2004): Comparative expression of NFkappaB proteins in melanocytes of normal skin vs. benign intradermal naevus and human metastatic melanoma biopsies. Pigment Cell Res 17, 173-180

Musacchio A, Salmon ED (2007): The spindle-assembly checkpoint in space and time. Nat Rev Mol Cell Biol $\underline{8}$, 379-393

Nazarian R, Shi H, Wang Q, Kong X, Koya RC, Lee H, Chen Z, Lee MK, Attar N, Sazegar H, et al. (2010): Melanomas acquire resistance to BRAF(V600E) inhibition by RTK or N-RAS upregulation. Nature $\underline{468}, 973-977$

Nissan MH, Pratilas CA, Jones AM, Ramirez R, Won H, Liu C, Tiwari S, Kong L, Hanrahan AJ, Yao Z, et al. (2014): Loss of NF1 in cutaneous melanoma is associated with RAS activation and MEK dependence. Cancer Res $\underline{74}$, $2340-2350$

Pahl HL (1999): Activators and target genes of Rel/NF-kappaB transcription factors. Oncogene $\underline{18}, 6853-6866$

Peng W, Chen JQ, Liu C, Malu S, Creasy C, Tetzlaff MT, Xu C, McKenzie JA, Zhang C, Liang X, et al. (2016): Loss of PTEN Promotes Resistance to T CellMediated Immunotherapy. Cancer Discov $\underline{6}$, 202-216

Piepkorn M (2000): Melanoma genetics: an update with focus on the CDKN2A(p16)/ARF tumor suppressors. J Am Acad Dermatol 42, 705-722; quiz 723-706

Piepkorn M: Genetic and Molecular Pathology of Melanoma. In: Barnhill R (Hrsg.): Pathology of Melanocytic Nevi and Melanoma. Third Edition; Springer, Heidelberg, New York, Dordrecht London 2014, 33-59 
Pletz N, Schon M, Ziegelbauer K, Emmert S, Liu N, Dobbelstein M, Schon MP (2012): Doxorubicin-induced activation of NF-kappaB in melanoma cells is abrogated by inhibition of IKKbeta, but not by a novel IKKalpha inhibitor. Exp Dermatol 21, 301-304

Prasad AV, Mohan N, Chandrasekar B, Meltz ML (1994): Activation of nuclear factor kappa $B$ in human lymphoblastoid cells by low-dose ionizing radiation. Radiat Res $\underline{138}$, 367-372

Proksch E, Brandner JM, Jensen JM (2008): The skin: an indispensable barrier. Exp Dermatol 17, 1063-1072

Ramos JC, Ruiz P, Jr., Ratner L, Reis IM, Brites C, Pedroso C, Byrne GE, Jr., Toomey NL, Andela V, Harhaj EW, et al. (2007): IRF-4 and c-Rel expression in antiviral-resistant adult T-cell leukemia/lymphoma. Blood 109, 30603068

Regad T (2013): Molecular and cellular pathogenesis of melanoma initiation and progression. Cell Mol Life Sci $\underline{70}$, 4055-4065

Rieder CL, Maiato H (2004): Stuck in division or passing through: what happens when cells cannot satisfy the spindle assembly checkpoint. Dev Cell $\underline{7}, 637-651$

Rodig SJ, Savage KJ, Nguyen V, Pinkus GS, Shipp MA, Aster JC, Kutok JL (2005): TRAF1 expression and c-Rel activation are useful adjuncts in distinguishing classical Hodgkin lymphoma from a subset of morphologically or immunophenotypically similar lymphomas. Am J Surg Pathol 29, 196-203

Saldanha G, Potter L, Daforno P, Pringle JH (2006): Cutaneous melanoma subtypes show different BRAF and NRAS mutation frequencies. Clin Cancer Res 12, 4499-4505

Samaniego E, Redondo P (2013): Lentigo maligna. Actas Dermosifiliogr $\underline{104}, 757-775$

Satyamoorthy K, Herlyn M (2002): Cellular and molecular biology of human melanoma. Cancer Biol Ther $\underline{1}, 14-17$

Schneider P, Schon M, Pletz N, Seitz CS, Liu N, Ziegelbauer K, Zachmann K, Emmert S, Schon MP (2014): The novel PI3 kinase inhibitor, BAY 80- 
6946, impairs melanoma growth in vivo and in vitro. Exp Dermatol $\underline{23}$, 579-584

Schon M, Wienrich BG, Kneitz S, Sennefelder H, Amschler K, Vohringer V, Weber O, Stiewe T, Ziegelbauer K, Schon MP (2008): KINK-1, a novel small-molecule inhibitor of IKKbeta, and the susceptibility of melanoma cells to antitumoral treatment. J Natl Cancer Inst $\underline{100}, 862-875$

Seitz CS, Lin Q, Deng H, Khavari PA (1998): Alterations in NF-kappaB function in transgenic epithelial tissue demonstrate a growth inhibitory role for NF-kappaB. Proc Natl Acad Sci U S A 95, 2307-2312

Seitz CS, Deng H, Hinata K, Lin Q, Khavari PA (2000a): Nuclear factor kappaB subunits induce epithelial cell growth arrest. Cancer Res $\underline{60}, 4085-$ 4092

Seitz CS, Freiberg RA, Hinata K, Khavari PA (2000b): NF-kappaB determines localization and features of cell death in epidermis. J Clin Invest $105,253-260$

Sen R, Baltimore D (1986): Inducibility of kappa immunoglobulin enhancer-binding protein Nf-kappa B by a posttranslational mechanism. Cell 47, 921-928

Shattuck-Brandt RL, Richmond A (1997): Enhanced degradation of IkappaB alpha contributes to endogenous activation of NF-kappaB in Hs294T melanoma cells. Cancer Res 57, 3032-3039

Shono Y, Tuckett AZ, Liou HC, Doubrovina E, Derenzini E, Ouk S, Tsai JJ, Smith OM, Levy ER, Kreines FM, et al. (2016): Characterization of a c-Rel Inhibitor That Mediates Anticancer Properties in Hematologic Malignancies by Blocking NF-kappaB-Controlled Oxidative Stress Responses. Cancer Res 76, 377-389

Siwak DR, Shishodia S, Aggarwal BB, Kurzrock R (2005): Curcumin-induced antiproliferative and proapoptotic effects in melanoma cells are associated with suppression of IkappaB kinase and nuclear factor kappaB activity and are independent of the B-Raf/mitogenactivated/extracellular signal-regulated protein kinase pathway and the Akt pathway. Cancer $\underline{104}$ 879-890 
Slipicevic A, Herlyn M (2015): KIT in melanoma: many shades of gray. J Invest Dermatol 135, 337-338

Smalley KS (2010): Understanding melanoma signaling networks as the basis for molecular targeted therapy. J Invest Dermatol 130, 28-37

Soengas MS, Lowe SW (2003): Apoptosis and melanoma chemoresistance. Oncogene $\underline{22}$, 3138-3151

Soura E, Eliades PJ, Shannon K, Stratigos AJ, Tsao H (2016): Hereditary melanoma: Update on syndromes and management: Genetics of familial atypical multiple mole melanoma syndrome. J Am Acad Dermatol $\underline{74}$, 395-407; quiz 408-310

Sumimoto H, Imabayashi F, Iwata T, Kawakami Y (2006): The BRAF-MAPK signaling pathway is essential for cancer-immune evasion in human melanoma cells. J Exp Med 203, 1651-1656

Sur I, Ulvmar M, Toftgard R (2008): The two-faced NF-kappaB in the skin. Int Rev Immunol 27, 205-223

Sutton SK, Carter DR, Kim P, Tan O, Arndt GM, Zhang XD, Baell J, Noll BD, Wang S, Kumar N, et al. (2016): A novel compound which sensitizes BRAF wild-type melanoma cells to vemurafenib in a TRIM16-dependent manner. Oncotarget $\underline{7}, 52166-52178$

Tian W, Liou HC (2009): RNAi-mediated c-Rel silencing leads to apoptosis of $B$ cell tumor cells and suppresses antigenic immune response in vivo. PLoS One $\underline{4}$, e5028

Ueda Y, Richmond A (2006): NF-kappaB activation in melanoma. Pigment Cell Res $\underline{19}$, 112-124

van Hogerlinden M, Rozell BL, Toftgard R, Sundberg JP (2004): Characterization of the progressive skin disease and inflammatory cell infiltrate in mice with inhibited NF-kappaB signaling. J Invest Dermatol $\underline{123}, 101-108$

Van Muijen GN, Cornelissen LM, Jansen CF, Figdor CG, Johnson JP, Brocker EB, Ruiter DJ (1991): Antigen expression of metastasizing and non-metastasizing human melanoma cells xenografted into nude mice. Clin Exp Metastasis $\underline{9}$, 259-272 
Walczak CE, Cai S, Khodjakov A (2010): Mechanisms of chromosome behaviour during mitosis. Nat Rev Mol Cell Biol 11, 91-102

Wang CY, Guttridge DC, Mayo MW, Baldwin AS, Jr. (1999): NF-kappaB induces expression of the $\mathrm{Bcl}-2$ homologue $\mathrm{A} 1 / \mathrm{Bfl}-1$ to preferentially suppress chemotherapy-induced apoptosis. Mol Cell Biol 19, 5923-5929

Weaver BA, Cleveland DW (2006): Does aneuploidy cause cancer? Curr Opin Cell Biol 18, 658-667

Whiteman DC, Whiteman CA, Green AC (2001): Childhood sun exposure as a risk factor for melanoma: a systematic review of epidemiologic studies. Cancer Causes Control 12, 69-82 


\section{Danksagung}

Zunächst gilt mein Dank Frau Prof. Dr. Cornelia S. Seitz, die das Forschungsprojekt betreut hat und durch ihre langjährige Forschungserfahrung und Expertise dieses Projekt überhaupt erst möglich gemacht hat. Ich danke für die gute und intensive Betreuung und die Geduld.

Des Weiteren gilt mein Dank Prof. Dr. Michael P. Schön, der es ermöglicht hat, dass ich in die Arbeitsgruppe des dermatologischen Forschungslabors aufgenommen wurde und meine Promotion dort absolvieren durfte. Sein Wissensspektrum und Forschungsverständnis haben diese Arbeit geprägt und maßgeblich vorangebracht.

Außerdem möchte ich mich bei Frau Dr. Verena Lorenz bedanken, die mich in meiner experimentellen Arbeit direkt betreut hat. Liebe Verena, ich danke dir für deine Unermüdlichkeit, deine Hilfsbereitschaft, dein immer offenes Ohr.

Im Weiteren möchte ich mich bei allen Mitarbeitern des Forschungslabores bedanken, die für das tolle Arbeitsumfeld verantwortlich waren. Insbesondere möchte ich mich bei Frau Ulla Unkelbach, Frau Anette Bennemann und Frau Karolin Zachmann bedanken. Ohne sie wären meine Experimente nicht in dieser Form möglich gewesen. Ich danke Ulla auch für die Aufmunterungen abseits des Labors. Weiterhin möchte ich mich bei Prof. Dr. Margarete Schön, Dr. Andrea Braun, Dr. Nadin Dewert und Dr. Katharina Amschler für ihre Unterstützung bedanken.

Ich möchte mich auch bei meinen Mit-Doktoranden Sebastian Rahrig, Ilkay Beyazpinar und Emilia Schmid bedanken, die sowohl gute Laune als auch Frustration gleichermaßen teilen konnten. 